ŠUMARSKI FAKULTET I INSTITUT ZA ŠUMARSTVO U SARAJEVU Posebna izdanja: broj 9

Terzić D.:

\title{
PROUČAVANJE HEMIJSKOG SASTAVA ZELENILA ŠUMSKOG DRVEĆA SIROVINE ZA PROIZVODNJU KONCENTRATA STOČNE HRANE
}



ŠUMARSKI FAKULTET I INSTITUT ZA ŠMARSTVO U SARAJEVU Posebna izdanja: broj 9

\author{
EX LIBRIS \\ Prof. dr. Ostoja s̀tojanew.
}

Terzić D.:

\title{
PROUČAVANJE HEMIJSKOG SASTAVA ZELENILA ŠUMSKOG DRVEĆA SIROVINE ZA PROIZVODNJU KONGEHTRATA STOČNE HRANE
}

Sarajevo, 1973. 


\section{ŠUMARSKI FAKULTET I INSTITUT ZA ŠUMARSTVO U SARAJEVU}

\section{Posebna izdanja \\ br. 9 ,}

Uređuje:

Komisija za redakciju naučnih i ostalih publikacija Šumarskog fakulteta i Instituta za šumarstro u Sarajevu

Prof. dr Davle Fukarek, predsjednik

Prof. dr Ostoja Stojanović, urednik

Drof. dr Konrad pinlarić

prof. dr Srelen Vučijak, sekretar

Doc. dr Čedomir Burlica

Dr Loli Manuševa, naučni savjetnik

Dripremljeno za štampanje decembra 1973, godine

Tiraž : 500 bomada

Uredništvo i administracija: Šumarski fakultet, Sarčjevo Zagrebačka 20 tel. (071) 611 033

Štampa: Radnički univerzitet „Đuro Đakovič“ Sarajevo, Đ. Đakovića 19 Za šlamparij.: Alilović Zvonko 


\section{PREDGOVOR AUTORA}

Rezultati proučavanja hemijskog sastava drvnog zelenila smrče, jele, belog bora, crnog bora, hrasta i bukve objavlieni su pod istim naslovom kao posebno izdanje Šumarskog fakulteta $i$ Instituta za šumarstvo u Sarajevu 1970.godine.

U ovoi publikaciji izvršili smo obradu rezultata proučavanja hemijskog sastava drvnog zelenila graba, jasena, topole, vrbe, bresta, ¡avora, breze i ¡ohe ${ }^{*}$, ti. većeg dela preostalih domaćih lišćara.

Obradu podataka izvršili smo na isti način kao što smo postupili u prvom slučaju. Proučavanja hemijskog sastava, zatim strukłurnih i težinskih odnosa sastavnih delova drvnog zelenila, izvršili smo po istoj metodici. Na ovaj način stvoreni su potrebni uslovi za medjusobna uporedjivanja rezultata proučavanja izmedju svih vrsta drveća u okviru isłog godišnjeg doba. Iz tog razloga smo se pri pisanju ovog rada zadržali veoma kratko na materiji koja je u objavljenoi publikaciji detalinije obuhvaćena. To znači da ovaj rad treba shvatiti kao aneks već objavljenog rada, tako da će obe publikacije činiti jednu zaokruženu celinu.

Pri ovakvom tretiranju problema kao celine izostavili smo u ovom delu rada sva uvodna razmatranja, zatim objašnjenja stručne terminologije, metodiku obrade zadatka $i$ opšta izlaganja o fiziološkom značaju vitamina $i$ mikroelemenata $u$ ishrani životinja (i ljudi).

$U$ pogledu stručne terminologije izvršili smo u ovom delu rada samo promenu naziva "tehničko zelenilo" u "drvno zelenilo". Novim izrazom se odredjenije deklariše o kojoj se sirovini radi, pošto u praksi postoji $i$ "travno zelenilo".

*) Puni narodni i latinski nazivi drveća dati su napred, dalje u tekstu služićemo se skraćenim nazivima. 
Sve hemijske analize drvnog zelenila izvršene su u Hemijskom institutu na Prirodno-matematičkom fakultetu u Sarajevu. Radovima su rukovodili doc.dr K. Dursun - Grom i asistent D.Murko, dipl.inž. Za uspešno izvršeni zadatak i na ukazanoj svestranoj pomoći pri izradi ovog rada najtoplije se zahvaljujemo.

Pripremanje uzoraka drvnog zelenila na terenu i dopremu u Sarajevo za hemijsku analizu, zatim sva druga merenja drvnog zelenila, izvršili su J.Pejanović, upravnik Eksperimentalne stanice u Maoči i B.Sirotanović, radnik $u$ istoj stanici (SI.1).

Na obradi podataka i pripremanju publikacije u Institutu svestrano je saradjivala tehn.Jurić.

\section{CILJ PROUČAVANJA}

Cilj proučavanja drvnog zelenila odabranih vrsta šumskog drveća je isti kao i pri proučavanju drvnog zelenila četinara, hrasta $i$ bukve. I pored toga smatramo da je potrebno $\mathrm{i}$ na ovom mestu da se ponovo istakne cilj ovih proučavanja. Taj cili je sledeći:

1. Proučiti hemijski sastav drvnog zelenila graba, jasena, topole, vrbe, bresta, javora, breze $i$ johe $i$ utvrditi vrste $i$ količine fiziološki aktivnih materija u cilju odredjivanja praktične vrednosti drvnog zelenila kao sirovine za proizvodnju vitaminsko-mineralnog brašna - koncentrata za prihranjivanje domaćih životinja, kao $\mathbf{i}$ drugih proizvoda od drvnog zelenila.

2. Proučiti strukturne $i$ težinske odnose izmedju sastavnih delova drvnog zelenila za pomenute vrste šumskog drveća u cilju utvrdjivanja na osnovnoj grančici debljine $10 \mathrm{~mm}$, učešće odredjenih dimenzija grančica sa korom, za-

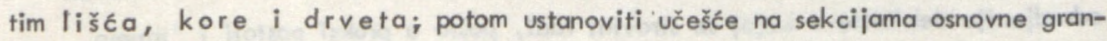
čice (debljine do $2 \mathrm{~mm}$, od 2-4mm, od 4-6 mm, od 6-8 mm i od \&-10 mm), grančica debljine do $2 \mathrm{~mm}$, od $2-4 \mathrm{~mm}$, od $4-6 \mathrm{~mm}$, od $6-8 \mathrm{~mm} \mathbf{i}$ od $8-10 \mathrm{~mm}$, već prema debljini sekcije osnovne grančice. 

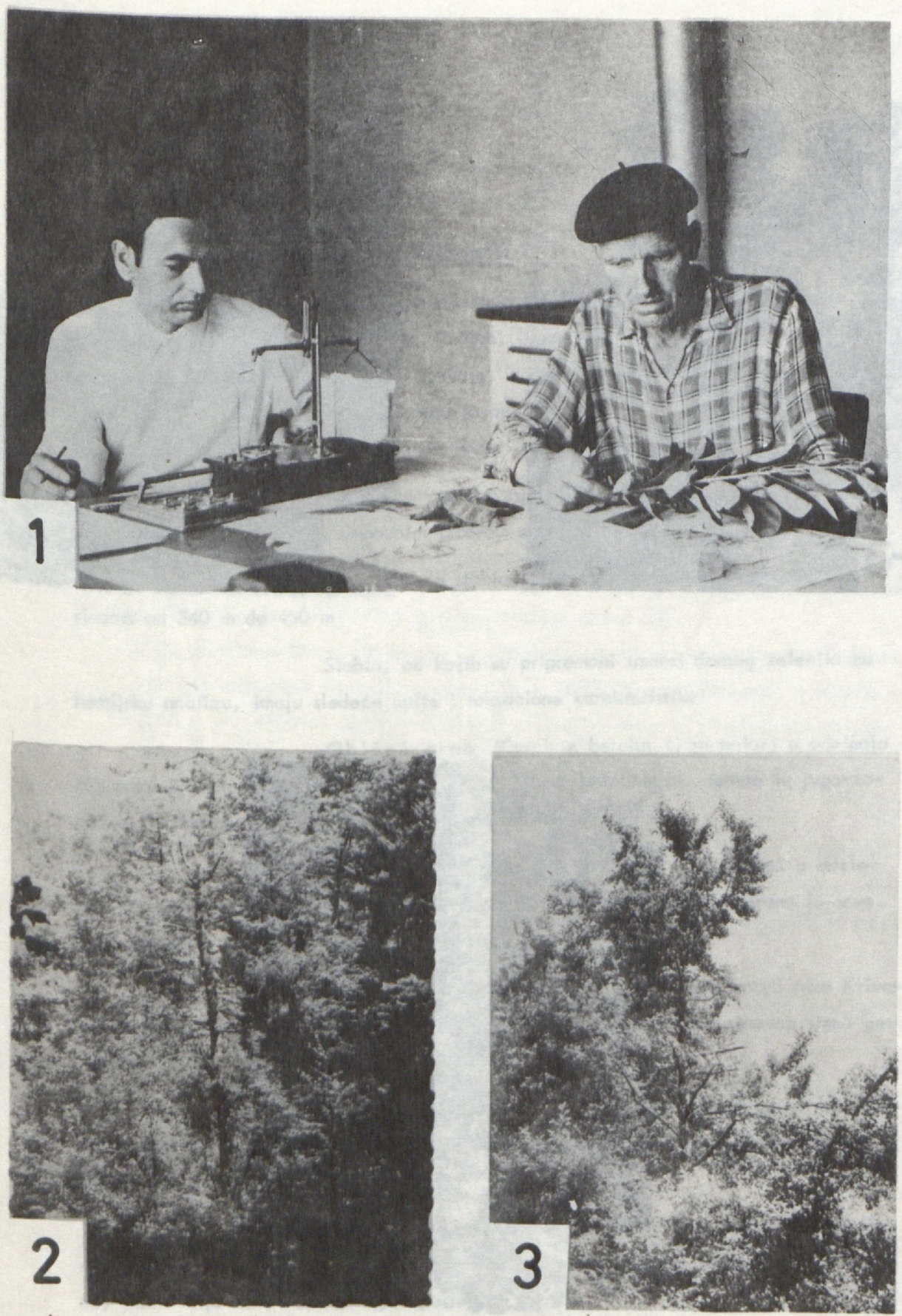

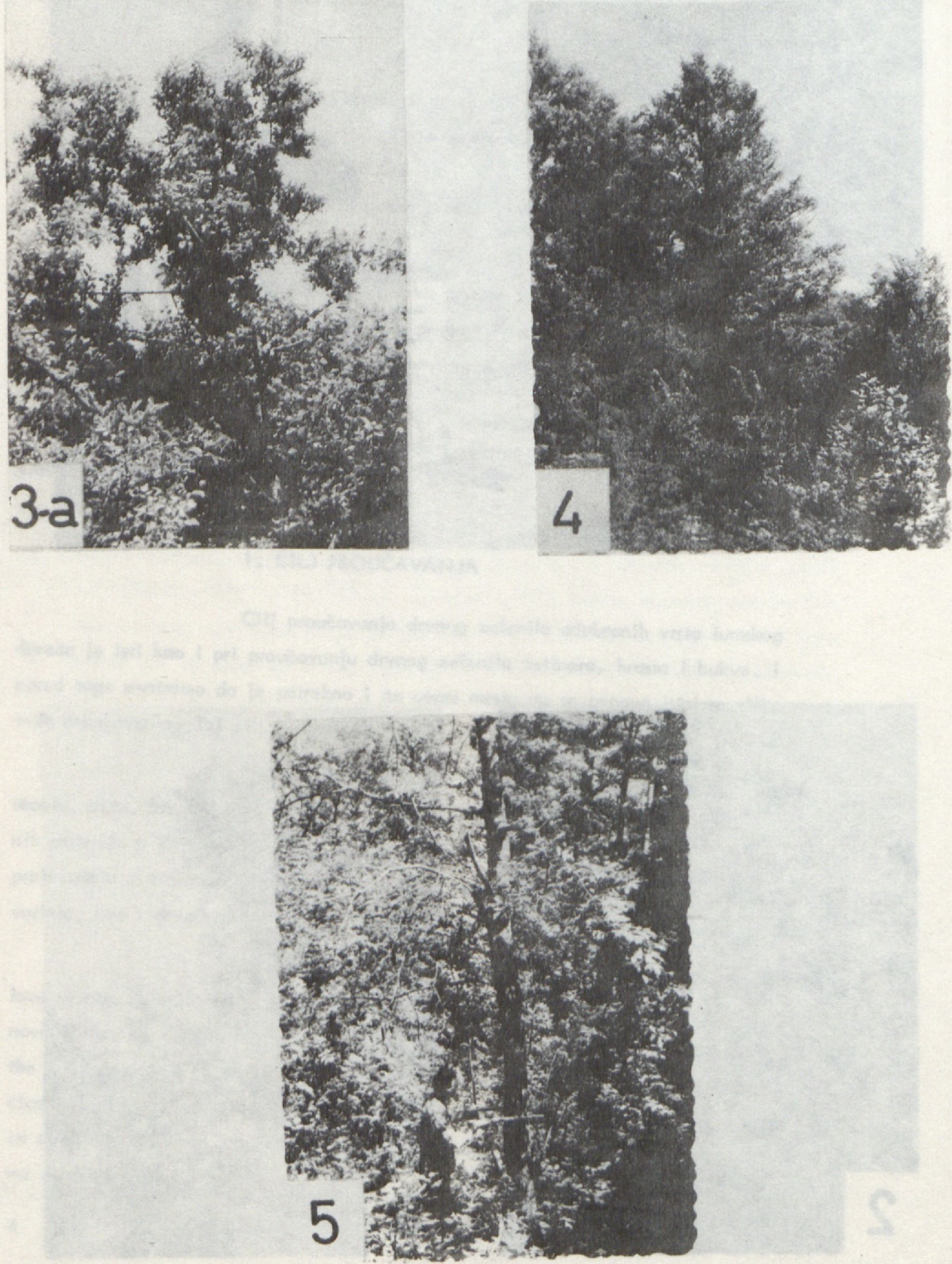


\subsection{Objekti proučavanja}

Objekti proučavanja su stabla, odnosno drvno zelenilo, graba, jasena, topole, vrbe, bresta, javora, breze $\mathbf{i}$ johe. Šira lokacija nalazišta pomenutih stabala jeste bazen reke Krivaje, a uža - područje bliže okoline Eksperimentalne stanice $u$ Maoči. Na terenu je odabrano po jedno stablo od svake vrste drveća. Od ovih stabala su pripremani uzorci drvnog zelenila za hemijsku analizu.

Uzorci za proučavanje strukturnih i težinskih odnosa drvenog zelenila pripremani su slobodnim izborom stabala $u$ istom području.

Sva izabrana stabla na terenu nalaze se na nadmorskim visinama od $340 \mathrm{~m}$ do $450 \mathrm{~m}$.

Stabla, od kojih su pripremani uzorci drvnog zelenila za hemijsku analizu, imaju sledeće opšte $i$ taksacione karakteristike:

Obični grab (Carpinus betulus L) se nalazi u odelenju 67; prsni promer ima $32 \mathrm{~cm}$ a ukupnu visinu $15 \mathrm{~m}$; ekspozicija terena je jugo-zapadna, a inklinacija $10^{\circ}$; osnovna stena peridotiti.

$$
\text { Bijeli jasen (Fraxinus excelsior L) se nalazi u odele- }
$$

nju 67; prsni promer ima $21 \mathrm{~cm}$ a ukupnu visinu $12 \mathrm{~m}$; ekspozicija terena je severo - zapadna, inklinacija $15^{\circ}$; osnovna stena peridotiti (SI.2).

$$
\text { Crna topola (Populus nigra L) se nalazi pored reke Kriva- }
$$
je; prsni promer ima $45 \mathrm{~cm}$ a ukupnu visinu $18 \mathrm{~m}$; teren je ravan; osnovna stena peridotiti (SI.3).

Bela vrba (Salix alba L) se takodje nalazi pored reke Krivaje; prsni promer ima $25 \mathrm{~cm}$ a ukupnu visinu $15 \mathrm{~m}$; tlo je ravno; osnovna stena peridotiti (SI. 3a).

$$
\text { Gorski brest (Ulmus montana With) se nalazi u odelenju }
$$
426; prsni promer ima $33 \mathrm{~cm}$ a ukupnu visinu $17 \mathrm{~m}$; ekspozicija terena je jugo-istočna, inklinacija $25^{\circ}$; osnovna stena peridotiti (SI.4). 
Mleč (Acer platanoides L) se nalazi u slivu potoka Dištice; prsni promer ima $20 \mathrm{~cm}$ a ukupnu visinu $8 \mathrm{~m}$; ekspozicija terena je jugo-istočna, inklinacija $25^{\circ}$, oshovna stena peridotiti.

Breza (Betula verrucosa Erh) se nalazi u slivu potoka Dištica; prsni promer ima $19 \mathrm{~cm}$ a ukupnu visinu $15 \mathrm{~m}$; ekspozicija terena je severro-zapadna, inklinacija $35^{\circ}$; osnovna stena peridotiti.

Crna joha (Alnus glutinosa Gaer) se nalazi u slivu potoka Dištice; prsni promer ima $37 \mathrm{~cm}$ a ukupnu visinu $10 \mathrm{~m}$; ekspozicija terena istočna, inklinacija $20^{\circ}$; osnovna stena peridotiti (SI.5).

\subsection{Proučavanje težinskih odnosa u drunom zelenilu}

Za ocenu vrednosti drvnog zelenila kao sirovine za proizvodnju koncentrata stočne hrane, potrebno je poznavati, pored hemijskog sastava i učešće u pomenutoj sirovini lišca, kore i drveta. Ova tri dela čine organsku mase drvnog zelenila u kojoj se nalaze fiziološki aktivne materije. Po sadržaju ovih materija na prvom mestu se nalazi lišcee, zatim kora i najzad drvo.

Rezultati proučavanja učešća u drvnom zelenilu lišća, kore i drveta na osnovnoi grančici debljine $10 \mathrm{~mm}$ na debljem kraju ${ }^{*}$ ) i na njenim sekcijama od 0-2 mm, 2-4 mm, 4-6 mm, 6-8 mm i 8-10 mm pokazani su u tabeli 1 i na grafikonima $1-8$.

Analizom podataka iz tabele 1 i grafikona 1-8 mogu se izvesti sledeće konstatacije:

1) Sve proučavane vrste šumskog drveća imaju na tanjim sekcijama osnovne grančice veću količinu lišč. To, drugim rečima, znači da sa povećanjem debliine osnovne grančice do $10 \mathrm{~mm}$ opada učešće lišča - najvrednijeg dela $u$ drunom zelenilu.

*) U daljem izlaganju upotrebljavaćemo za osnovnu grančicu skraćeni izraz "od $10 \mathrm{~mm}$ debljine" ili samo "osnovna grančica". 
TEŽINSKI ODNOSI SASTAVNIH DELOVA TEHINIČKOG ZELENILA

(naturalni i procentualni poḳazatelịi)

Tabela 1.

\begin{tabular}{lllllllll}
\hline Redni & Deblina & \multicolumn{3}{c}{ Težina, gr } & \multicolumn{3}{c}{ \% od cele težine sekcije } \\
\cline { 3 - 10 } $\begin{array}{l}\text { broi } \\
\text { sekcije }\end{array}$ & $\begin{array}{l}\text { sekcije } \\
\text { u mm }\end{array}$ & $\begin{array}{l}\text { cele } \\
\text { sekcije }\end{array}$ & lišća & kore & drveta & lišća & kore & drveta \\
\hline 1 & 2 & 3 & 4 & 5 & 6 & 7 & 8 & 9 \\
\hline
\end{tabular}

Grab

$\begin{array}{lrrrrrrrr}\text { I } & \text { do } 2 & 2,19 & 1,68 & 0,26 & 0,25 & 77 & 12 & 11 \\ \text { II } & 2-4 & 10,34 & 7,31 & 1,20 & 1,83 & 71 & 11 & 18 \\ \text { III } & 4-6 & 26,51 & 17,22 & 3,45 & 5,84 & 65 & 13 & 22 \\ \text { IV } & 6-8 & 36,34 & 20,91 & 5,14 & 10,29 & 58 & 14 & 28 \\ \text { V } & 8-10 & 64,34 & 35,61 & 9,34 & 19,39 & 55 & 15 & 30 \\ & & 139,72 & 82,73 & 19,39 & 37,60 & 59 & 14 & 27\end{array}$

Jasen

$\begin{array}{lrrrrrrrr}\text { I } & \text { do } 2 & - & - & - & - & - & - & - \\ \text { il } & 2-4 & 9,66 & 7,79 & 1,28 & 0,59 & 81 & 13 & 6 \\ \text { III } & 4-6 & 19,34 & 11,94 & 3,99 & 3,41 & 62 & 21 & 17 \\ \text { IV } & 6-8 & 36,25 & 19,51 & 8,45 & 8,29 & 54 & 23 & 23 \\ \text { V } & 8-10 & 53,90 & 25,29 & 13,53 & 15,08 & 47 & 25 & 28 \\ & & 119,15 & 64,53 & 27,25 & 27,37 & 54 & 23 & 23\end{array}$

Topola

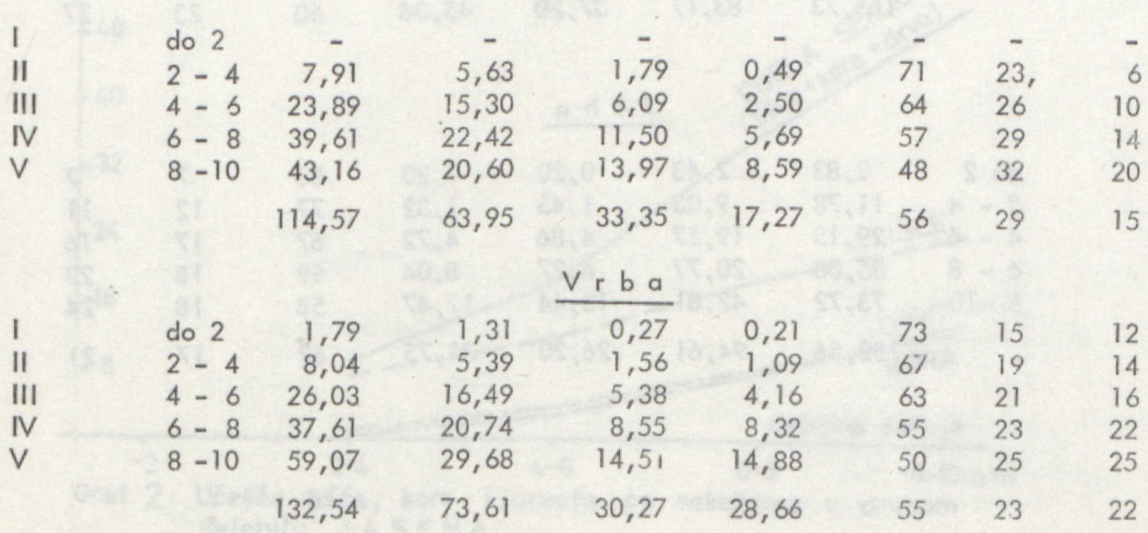


Nastavak tabele 1.

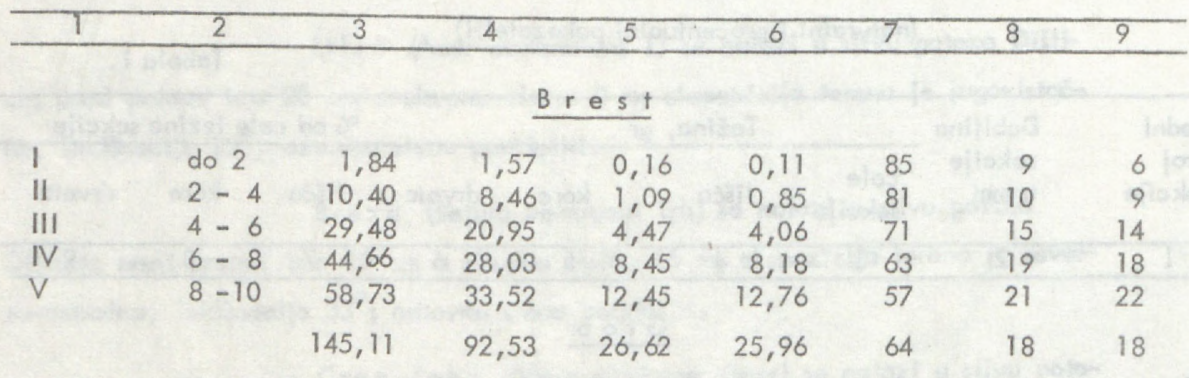

\section{Javor}

\begin{tabular}{|c|c|c|c|c|c|c|c|c|}
\hline & do 2 & - & - & - & - & - & - & - \\
\hline II & $2-4$ & 7,52 & 5,28 & 1,07 & 1,17 & 70 & 14 & 16 \\
\hline III & $4-6$ & 30,62 & 23,80 & 3,11 & 3,71 & 78 & 10 & 12 \\
\hline IV & $6-8$ & 51,02 & 33,11 & 7,66 & 10,25 & 65 & 15 & 20 \\
\hline V & $8-10$ & 72,58 & 41,90 & 11,97 & 18,71 & 58 & 16 & 26 \\
\hline & & 161,74 & 104,09 & 23,81 & 33,84 & 64 & 15 & 21 \\
\hline
\end{tabular}

\section{Breza}

$\begin{array}{lrrrrrrrr}\text { I } & \text { do } 2 & 2,02 & 1,57 & 0,32 & 0,13 & 78 & 16 & 6 \text {, } \\ \text { II } & 2-4 & 11,71 & 7,76 & 2,27 & 1,68 & 66 & 19 & 15 \\ \text { III } & 4-6 & 33,88 & 18,69 & 7,28 & 7,91 & 55 & 22 & 23 \\ \text { IV } & 6-8 & 59,09 & 28,34 & 13,41 & 17,34 & 48 & 23 & 29 \\ \text { V } & 8-10 & 59,03 & 26,81 & 13,92 & 18,30 & 45 & 24 & 31 \\ & & 165,73 & 83,17 & 37,20 & 45,36 & 50 & 23 & 27\end{array}$

\begin{tabular}{lrrrrrrrrr}
\cline { 5 - 6 } & \multicolumn{8}{c}{ Joh a } \\
I & do 2 & 2,83 & 2,43 & 0,20 & 0,20 & 86 & 7 & 7 \\
II & $2-4$ & 11,78 & 9,03 & 1,43 & 1,32 & 77 & 12 & 11 \\
III & $4-6$ & 29,15 & 19,57 & 4,86 & 4,72 & 67 & 17 & 16 \\
IV & $6-8$ & 35,08 & 20,77 & 6,27 & 8,04 & 59 & 18 & 23 \\
V & $8-10$ & 73,72 & 42,81 & 13,44 & 17,47 & 58 & 18 & 24 \\
& & 152,56 & 94,61 & 26,20 & 31,75 & 62 & 17 & 21
\end{tabular}




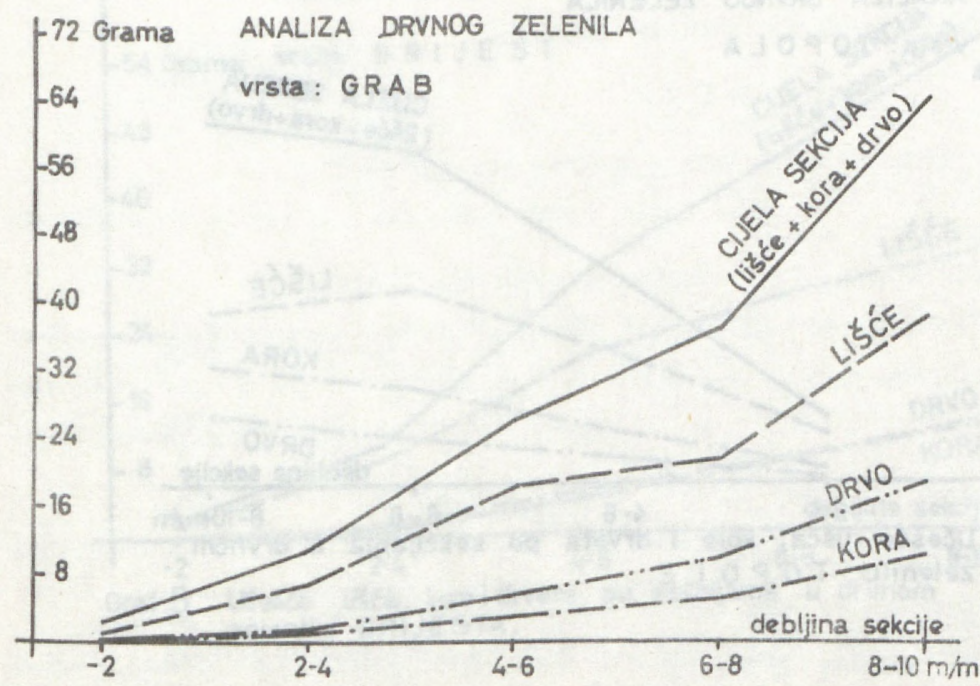

Graf. 1 Utešće lišća, kore i drveta po sekcijama u drvnom zelenilu GRABA.

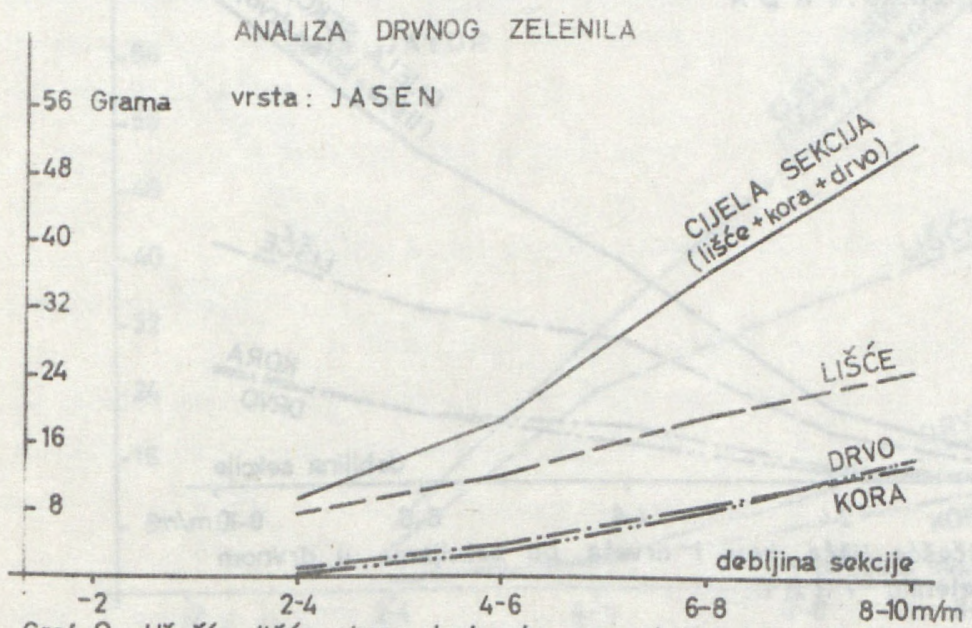

Graf. 2 Učesće lišća, kore i drveta po sekcijama u drvnom zelenilu JASENA. 


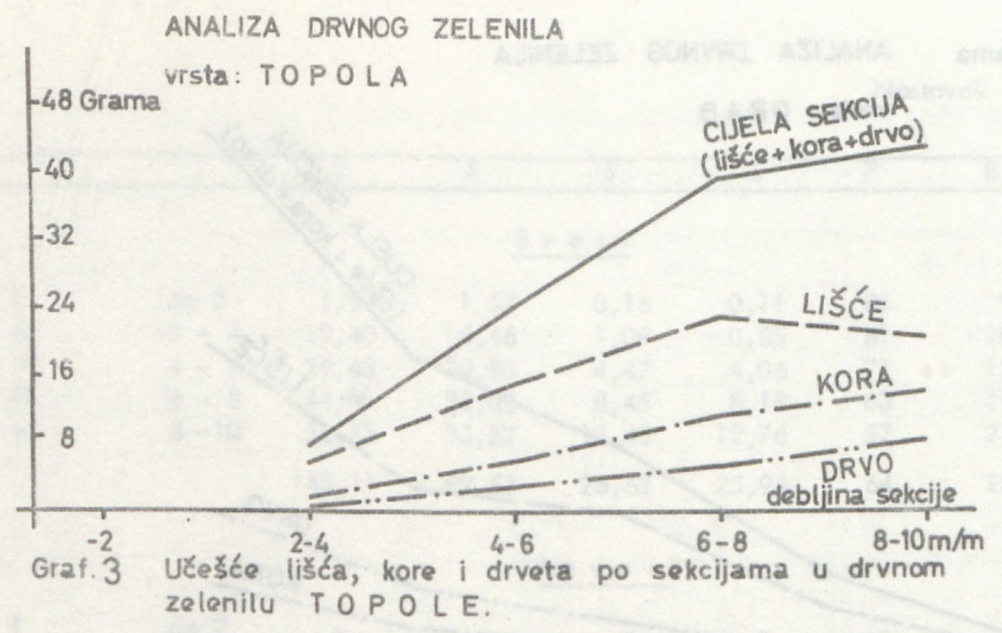

ANALIZA DRVNOG ZELENILA

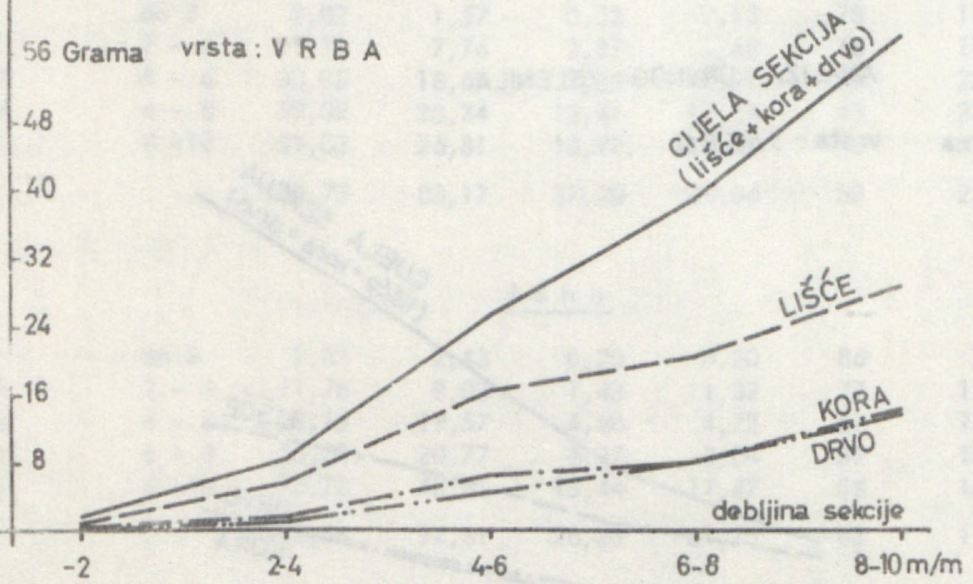

Graf. 4 Uteste lisća, kore i drveta po sekcijama u drvnom zelenilu VRBE. 


\section{ANALIZA DRVNOG ZELENILA}

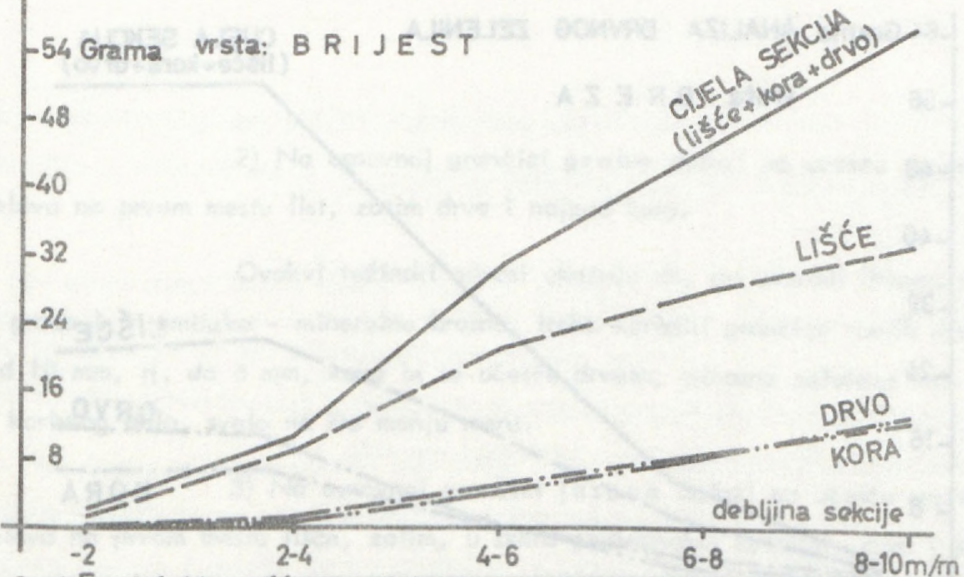

Graf.5 Utesce lișća, kore idrveta po sekcijama u drvnom zelenilu BRIJESTA.

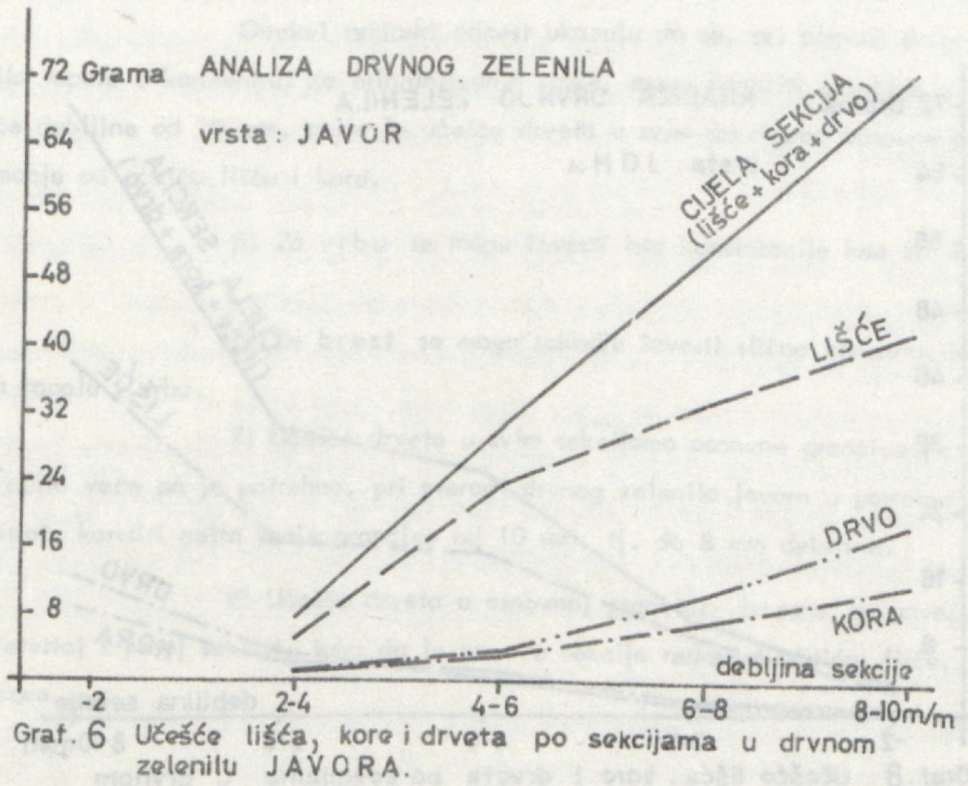



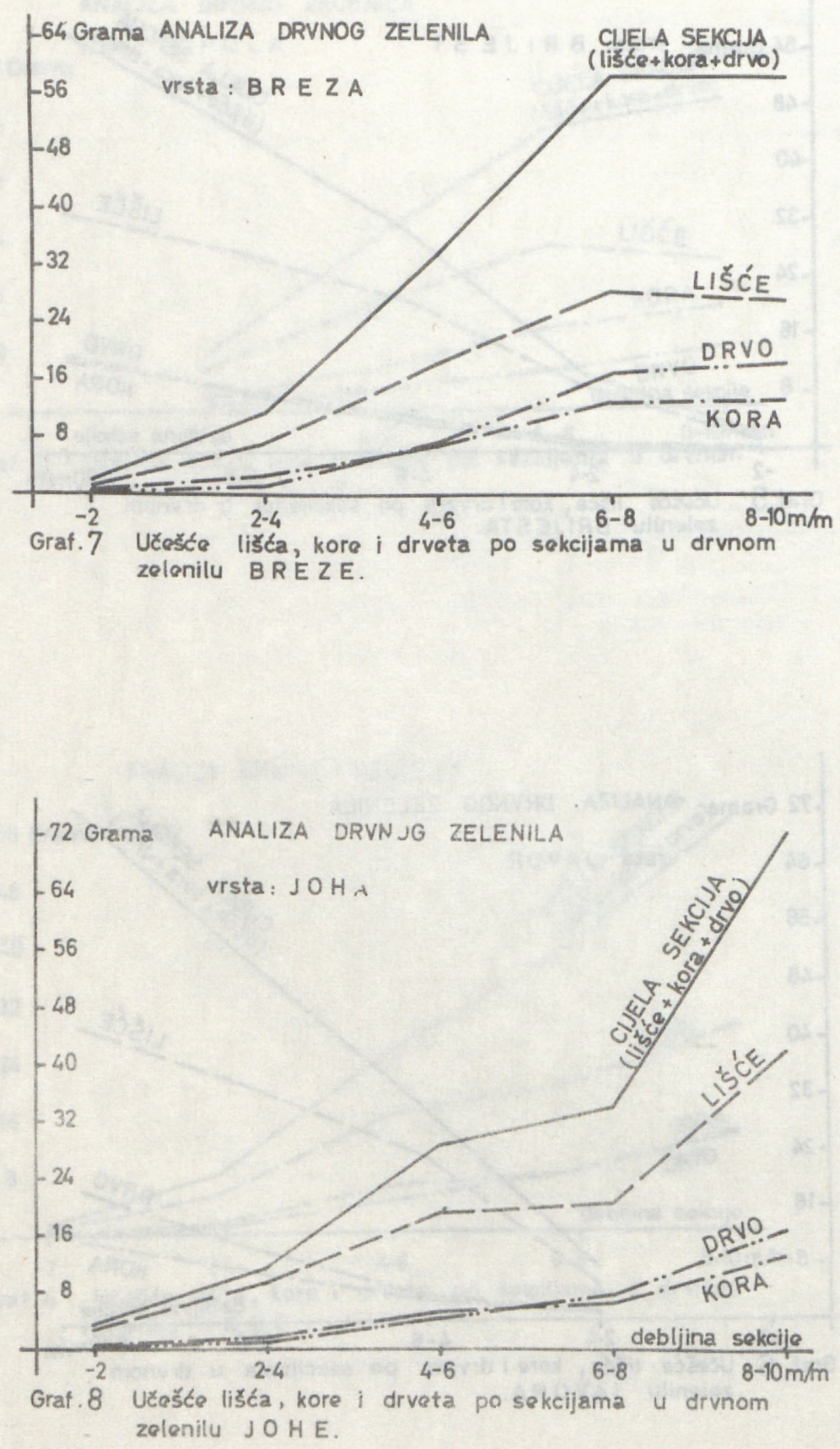
2) Na osnovnoi grančici graba dolazi po učešću sastavnih delova na prvom mestu list, zatim drvo i najzad kora.

Ovakvi težinski odnosi ukazuju da, pri preradi drvnog zelenila graba u vitaminsko - mineralno brašno, treba koristiti grančice tanjih dimenzija od $10 \mathrm{~mm}$, ti. do $6 \mathrm{~mm}$, kako bi se včešće drveta, odnosno celuloze kao najmanje korisnog dela, svelo na što manju meru.

3) Na osnovnoj grančici jasena dolazi po učešću sastavnih delova na prvom mestu lišće, zatim, u skoro podjednakoj količini, drvo i kora.

Ovakvi težinski odnosi ukazuju da se, pri preradi drvnog zelenila jasena, mogu koristiti nešto deblje grančice nego od graba, konkretno do $8 \mathrm{~mm}$, pošto se učešće kore kao aktivnijeg dela grančica povećava sa povećanjen. učesca drveta, odnosno debljine grančica.

4) Na osnovnoi grančici topole dolazi po učešću sastavnih delova na prvom mestu lišće, zatim kora i najzad drvo.

Ovakvi težinski odnosi ukazuju da se, pri preradi drvnog zelenila topole $u$ koncentrat za prihranjivanje stoke, mogu koristiti grančice do najveće debljine od $10 \mathrm{~mm}$, pošto je učešće drveta u svim sekcijama osnovne srančice manje od učešća lišća i hore.

5) Za vrbu se mogu izvesti iste konstatacije kao za topolu.

6) Za brest se mogu takodie izvesti slične konstatacije kao za topolu i vrbu.

7) Učešće drveła u svim sekcijama osnovne grančice javora je nešto veće pa je potrebno, pri preradi drvnog zelenila javora u pomenut: koncentrat, korstiti nešto tanje grančice od $10 \mathrm{~mm}$, ti. do $8 \mathrm{~mm}$ debljine.

8) Učešće drveta u osnovnoi grančici breze se povećava u četvrtoi i petoj sekciji, tako da je za ove sekcije redosled učešća: lisće, drvo, kora. 
Ovakvi težinski odnosi ukazuju da, pri preradi drvnog zelenila breze u koncentrat, treba koristiti grančice do $8 \mathrm{~mm}$ debljine u cilju smanjenja učešća celuloze.

9) Za johu se može izvesti slična konstatacija kao za brezu.

Težine celih osnovnih grančica do $10 \mathrm{~mm}$ debljine po vrstama drveća $\mathrm{i}$ njenih sastavnih delova u naturalnim i procentualnim pokazateljima pokazane su u tabeli 1 (Zbirno - poslednji redovi).

Analizom tih podataka mogu se izvesti sledeće konstatacije:

1. Javor ima najveću težinu osnovne grančice deblijine do $10 \mathrm{~mm}$ i ona iznosi $161,74 \mathrm{gr}$.

2. U odnosu na težinu cele osnovne grančice do $10 \mathrm{~mm}$ debljine najviše lišća imaju javor, zatim brest $\mathrm{i}$ grab, a najmanje jasen $\mathrm{i}$ vrba.

3. Prema učešću kore na osnovnoi grančici do $10 \mathrm{~mm}$ debljine, na prvom mestu se nalazi jasen, zatim brest a na poslednjem grab.

4. Prema učešću drveta u osnovnoi grančici do $10 \mathrm{~mm}$ debljine, na prvom mestu se nalazi grab $\mathrm{i}$ breza, zatim jasen, javor $\mathrm{i}$ joha, a na poslednjem brest $\mathrm{i}$ topola.

Prema učešću drveta u osnovnoi grančici, kao što je napred istaknuto, donosi se odluka u praksi do koje će se debljine grančica formirati drvno zelenilo kao sirovina za proizvodnju vitaminsko-mineralnog brašna. U praksi se obično nastoji da se učešće drveta, odnosno celuloze, u koncentratu svede na što manju meru, vodeći računa da se oceni prava mera, kako se ne bi suviše smanjio procenat iskorišćenja sirovine. Obično se postupa tako da se za prihranjivanje brojlera (živine) i prasadi, proizvodi koncentrat sa manje celuloze a za prihranjivanje ostalih životinja, a naročito preživara, u koncentratu može biti nešto veća količina celuloze. Svi ovi odnosi, kao i ostali pokazatelji, rešavaju se standardom o kvalitetu vitaminsko mineralnog brašna.

Mapred izvedena analiza o sekcijama na osnovnoi grančici do $10 \mathrm{~mm}$ debljine, može se konstatovati da prvu sekciju (do $2 \mathrm{~mm}$ debljine) imaju 
grab, vrba, breza, brest, $\mathrm{i}$ joha, dok jasen, topola $\mathrm{i}$ javor nemaju ovu sekciju.

\subsection{Proučavanje strukturnih odnosa u drvnom zelenilu:}

Da bi utvrdili za svaku proučavanu vrstu drveća strukturni sastav osnovne grančice do $10 \mathrm{~mm}$ debljine izvršili smo po 20 merenja za svaku vrstu drveća.

Pod strukturnim sastavom osnovne grančice podrazumevaju se težine svake pojedine sekcije bez lišća, koje su razvrstane po debljinama, i to: do $2 \mathrm{~mm}$, od 2-4 mm, od 4-6 mm, od 6-8 mm i od 8-10 mm, zatim težine lišća od svake sekcije $\mathrm{i}$ najzad težine grančica sa korom, takodje od svake sekcije, razvrstanih po debljinama, $i$ to: do $2 \mathrm{~mm}$, od $2-4 \mathrm{~mm}$, od $4-6 \mathrm{~mm}$, od $6-8 \mathrm{~mm} i$ od 8-10 $\mathrm{mm}$, već prema debljini sekcije.

Poznavajući strukturni sastav osnovne grančice za svaku sekciju u stanju smo da odredimo, opet za svaku sekciju ili više sekcija osnovne grančice do $10 \mathrm{~mm}$ debljine, učešće lišća $\mathbf{i}$ grančica sa korom odredjenih debljina. Smanjivanjem učešća grančica u drvnom zelenilu, naročito grančica većih dimenzija, povećavaju se $u$ koncehtratu količine fiziološki aktivnih materija, pošto se povećava količina lišća $i$ kore a smanjuje učešce drveta, odnosno celuloze. To znači da se korištenjem drunog zelenila od tanjih grančica kao sirovine za preradu poboljšava kvalitet koncentrata - vitaminsko - mineralnog braška. Sa poboljšanjem kvaliteta koncentrata povećava se $\mathrm{i}$ njegova prodajna cena.

Rezultati proučavanja strukturnog sastava osnovne grančice pokazani su u tabeli 2, koja se sastoji od dva dela (I i II deo).

U prvom delu tabele pokazane su za svaku sekciju osnovne grančice kao i za celu grančicu, težine lišca $i$ grančica sa korom razvrstanih po debliinama od $2 \mathrm{~mm}$ (do $2 \mathrm{~mm}, 2-4 \mathrm{~mm}, 4-6 \mathrm{~mm}, 6-8 \mathrm{~mm}$ i $8-10 \mathrm{~mm}$ ). $U$ istom delu tabele pokazani su $\mathrm{i}$ procenti učešća $u$ odnosu na ukupnu težinu svake pojedine sekcije, odnosno cele osn甲vne grančice.

U drugom delu tabele 2 pokazano je, za svaku sekciju osnow ne grančice težinsko $i$ procentualno učešće lišća $i$ grančica sa korom po debljinama u odnosu na ukupnu težinu cele osnovne grančice. 


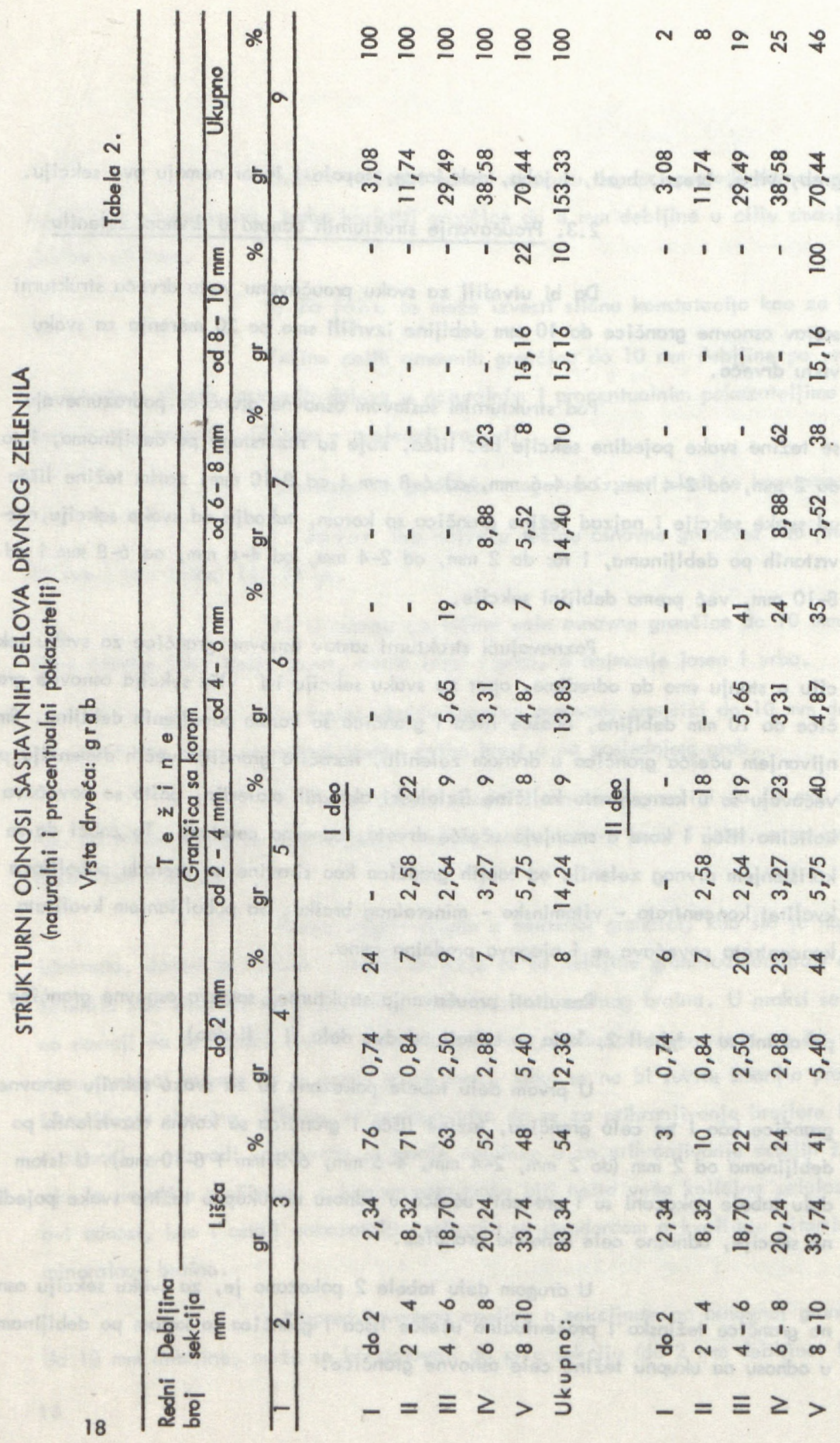




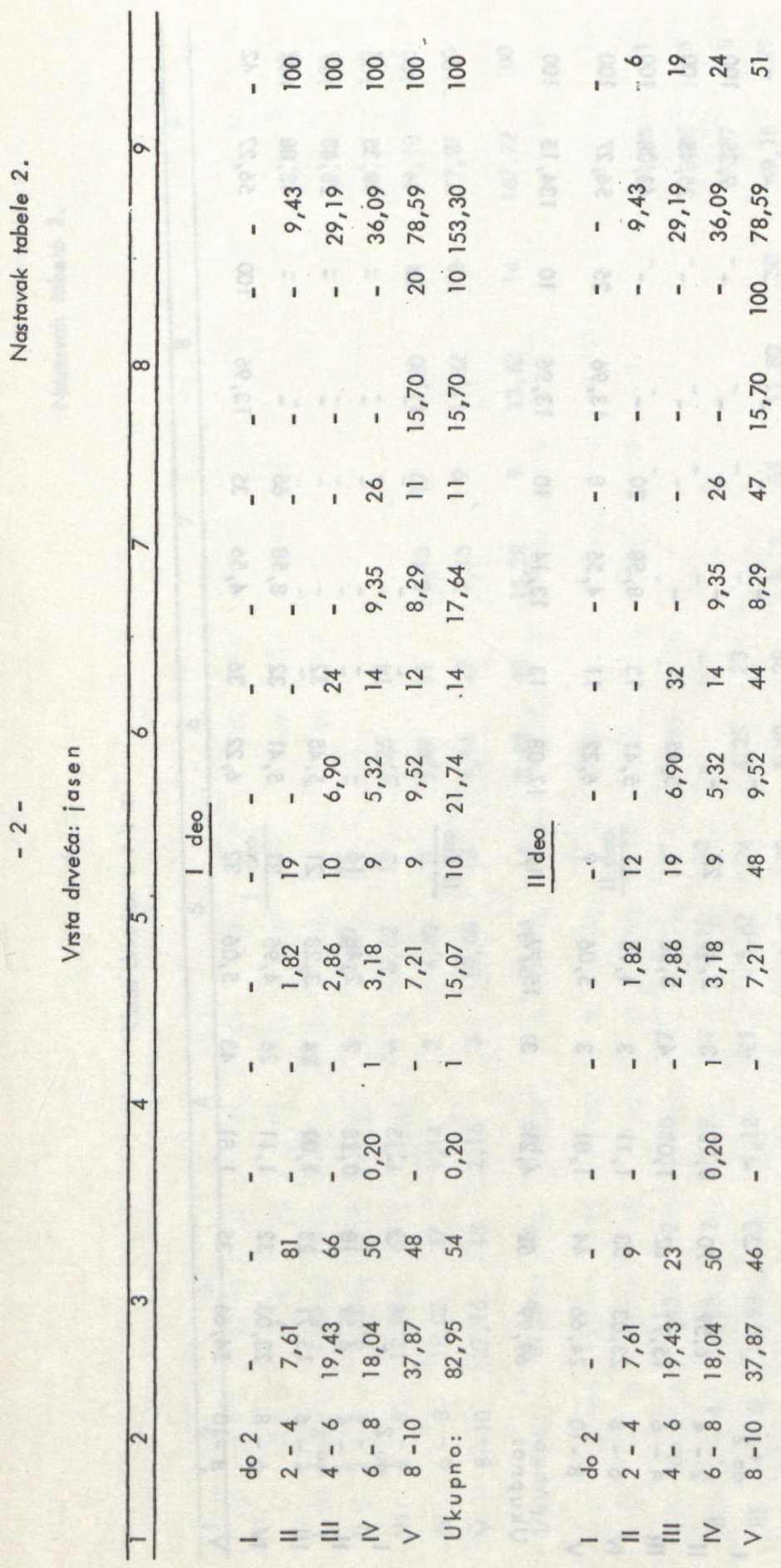




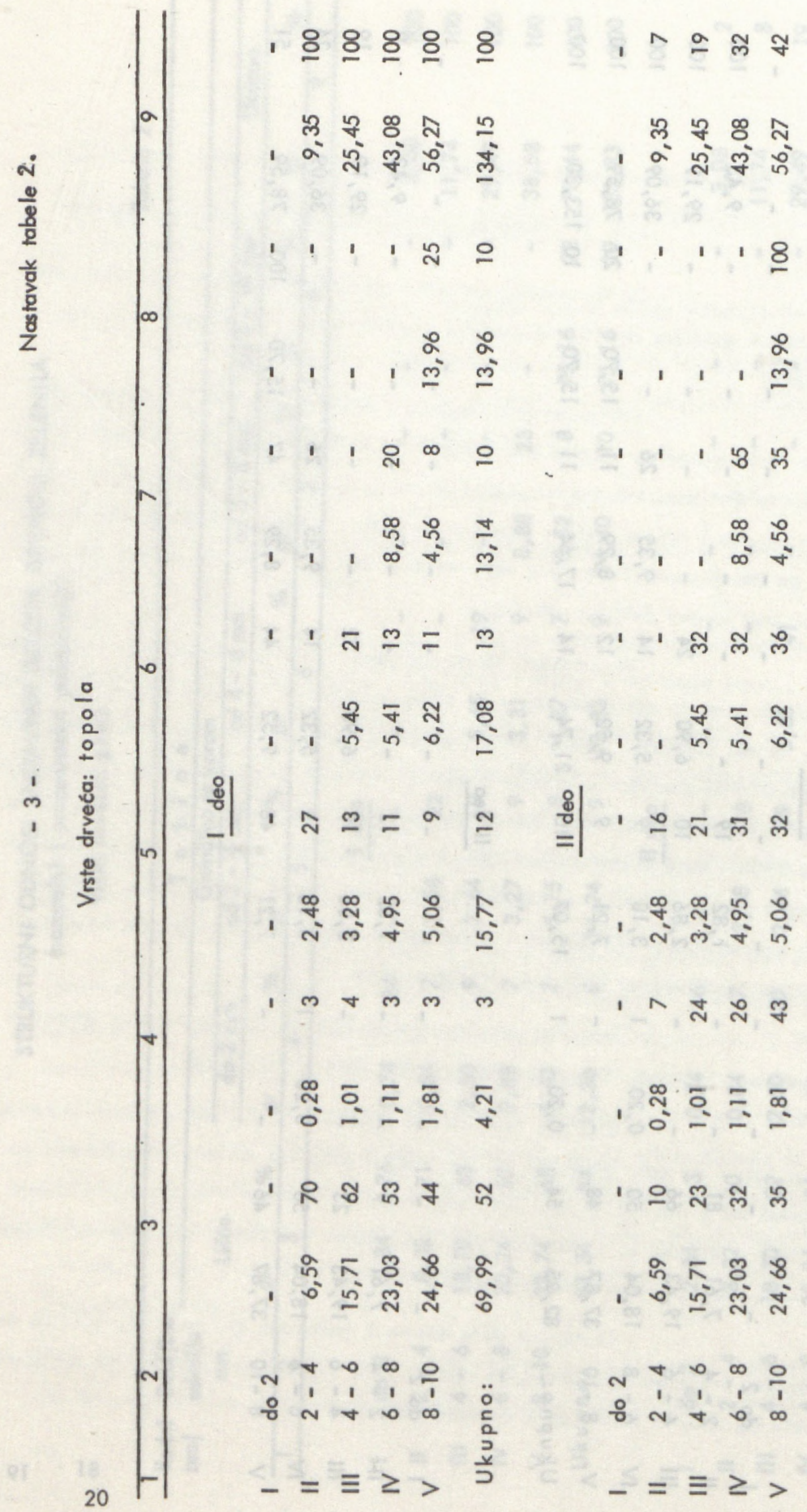




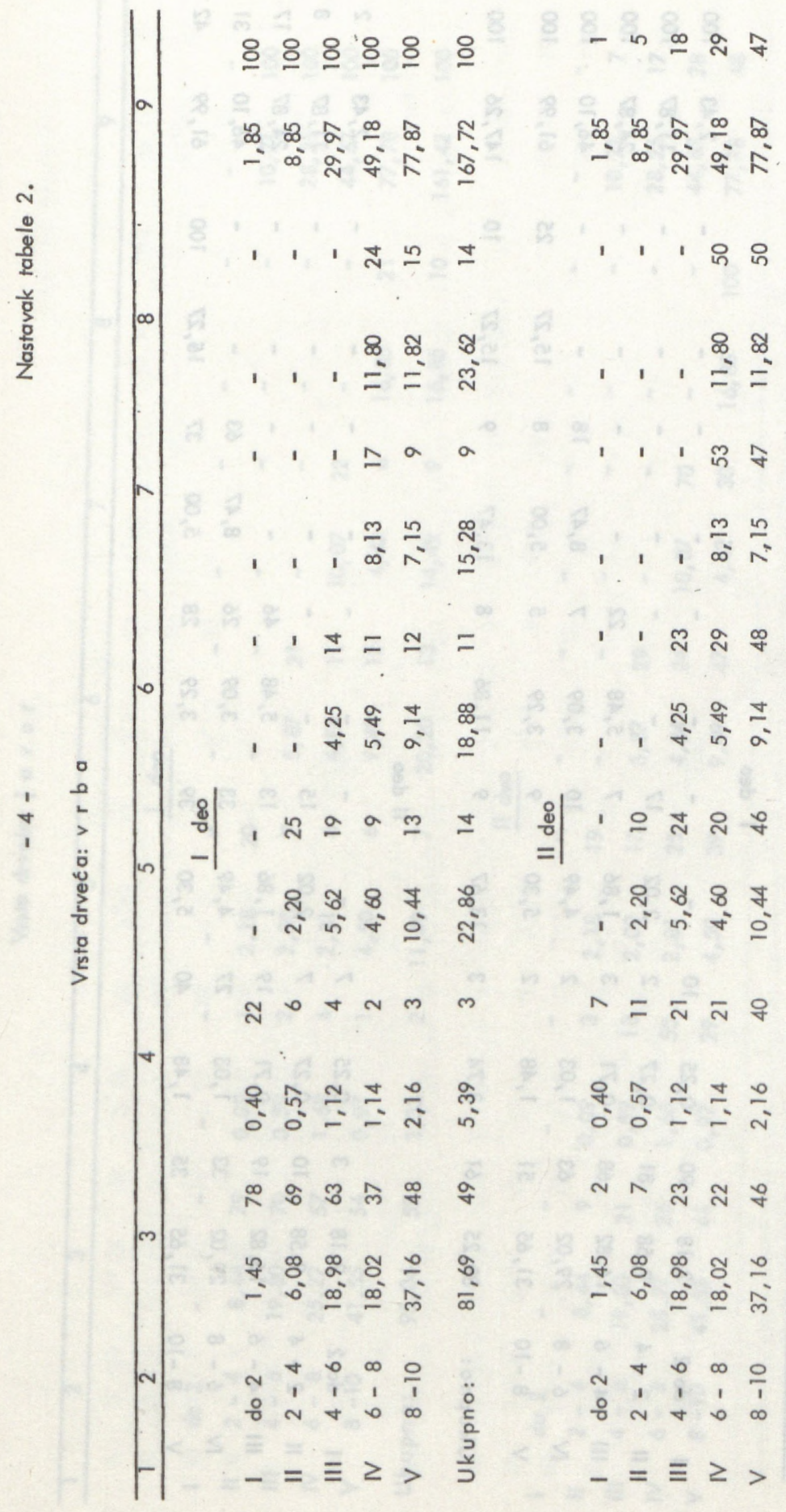




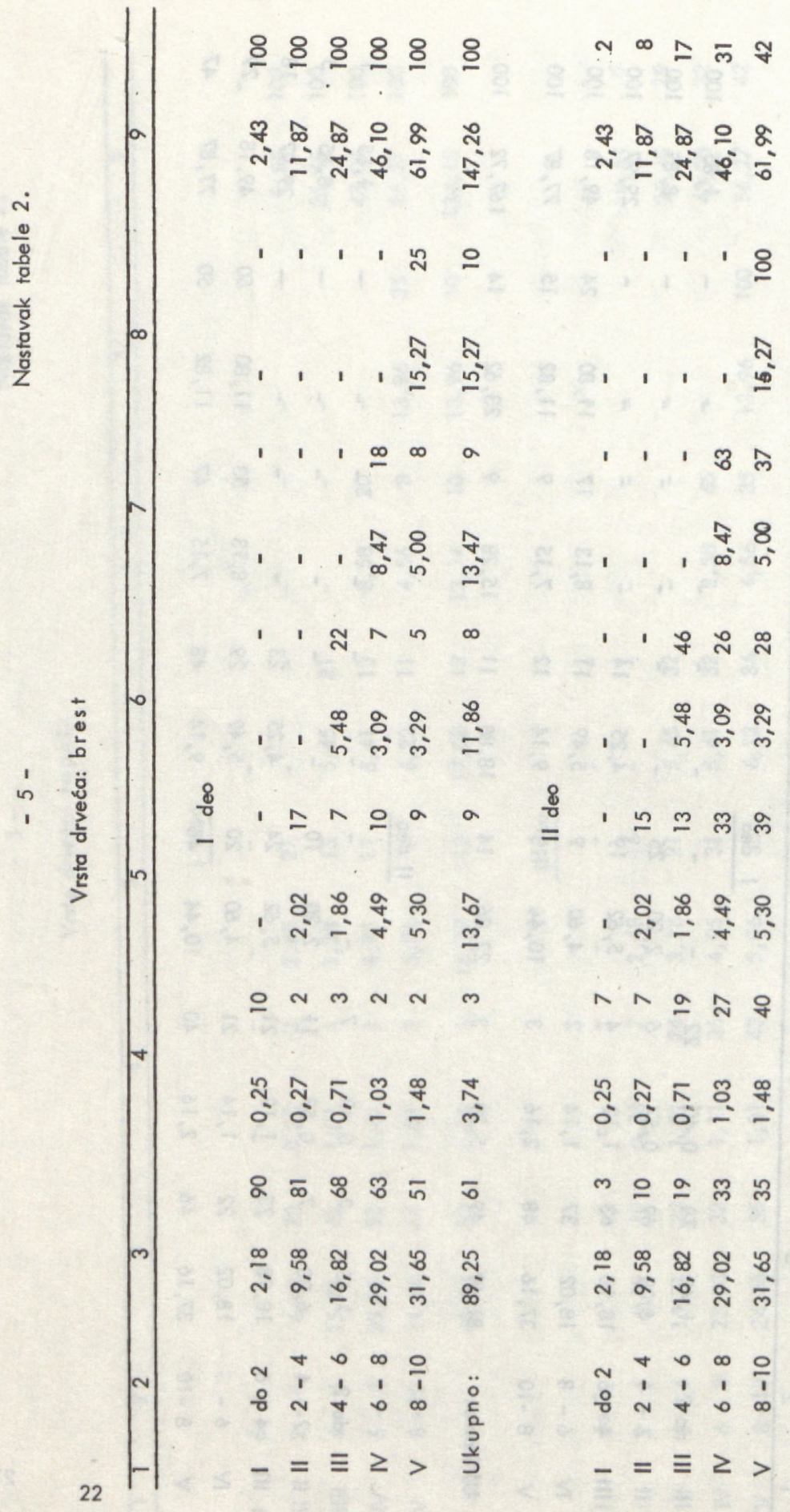




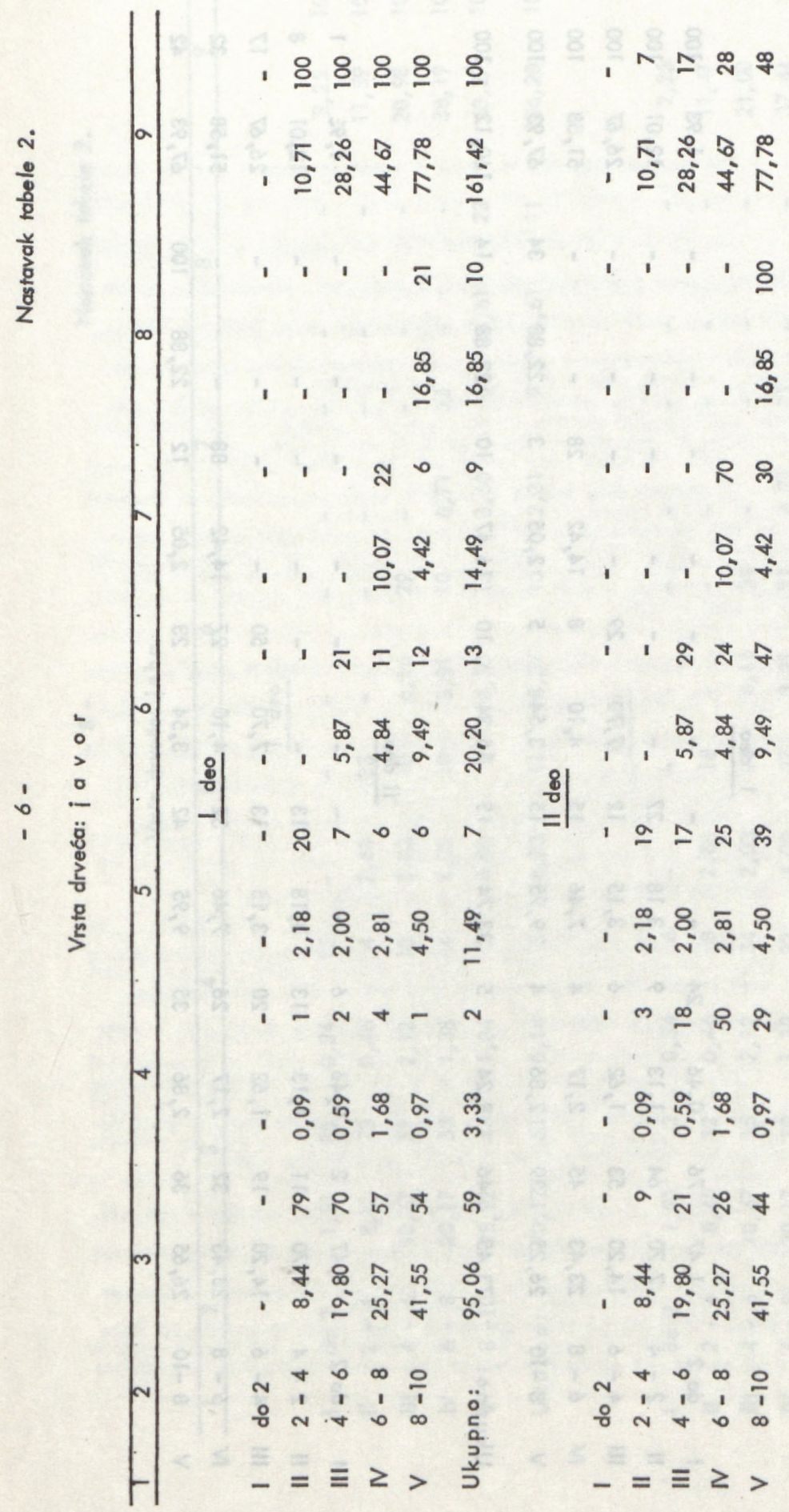




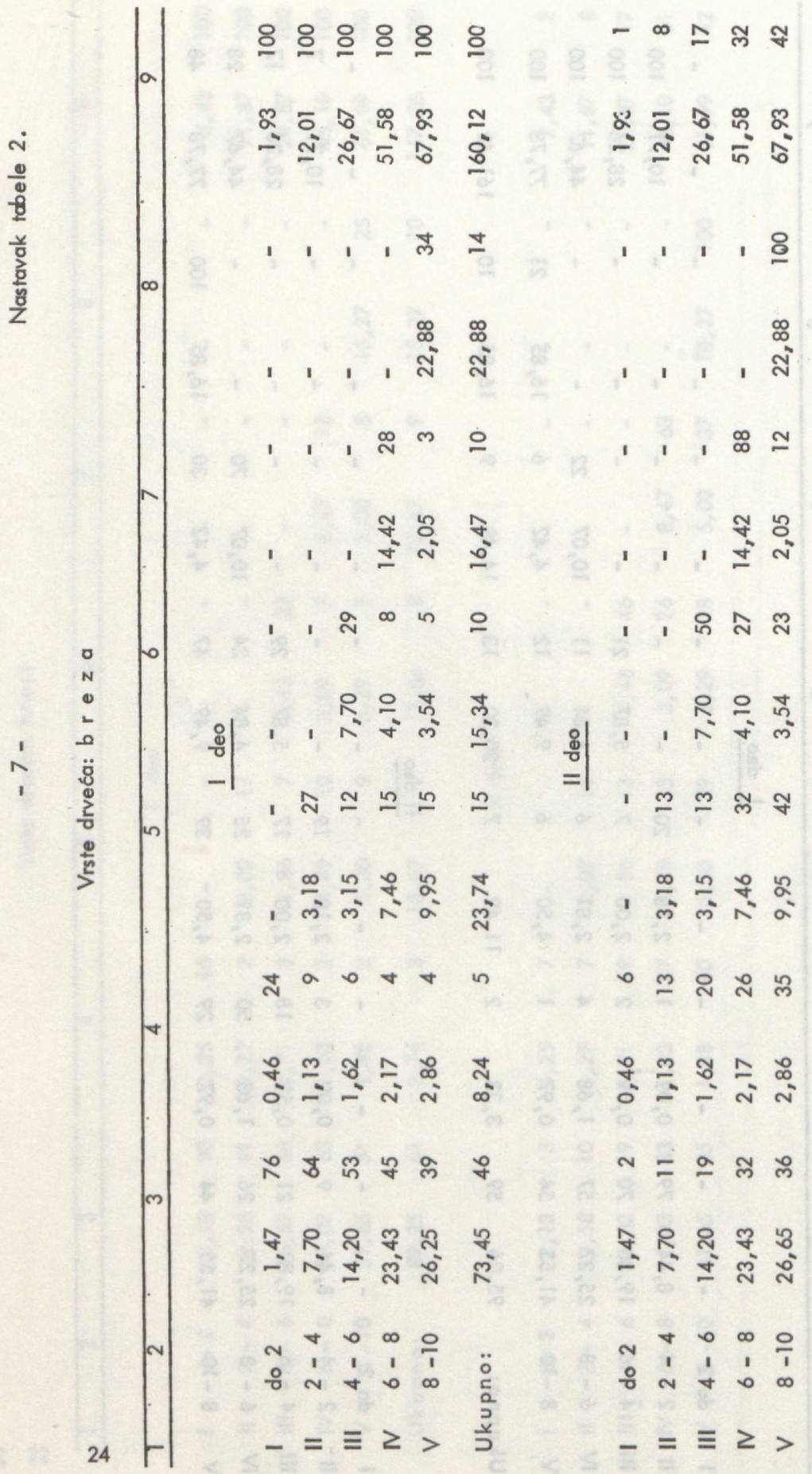




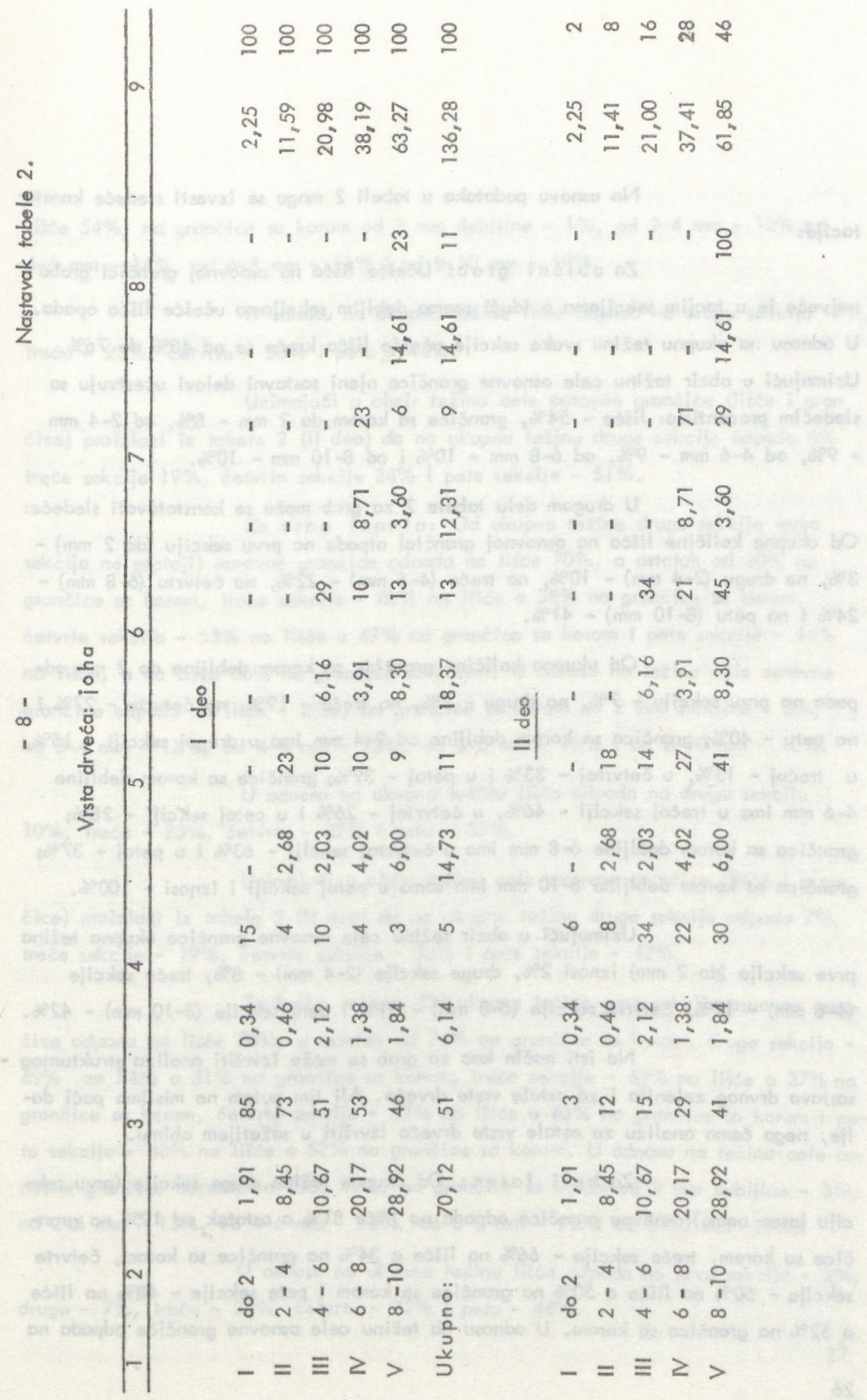


Na osnovu podataka u tabeli 2 mogu se izvesti sledeće konstatacije:

Za obični grab: Učešçe lišća na osnovnoi grančici graba najveće je u tanjim sekcijama a idući prema debljim sekcijama učešće lišća opada. U odnosu na ukupnu težinu svake sekcije učešće lišća kreće se od $48 \%$ do $76 \%$. Uzimajući u obzir težinu cele osnovne grančice njeni sastavni delovi učestvuju sa sledećim procentima: lišće - 54\%, grančice sa korom do $2 \mathrm{~mm}-8 \%$, od 2-4 mm - $9 \%$, od $4-6 \mathrm{~mm}-9 \%$, od $6-8 \mathrm{~mm}-10 \%$ i od $8-10 \mathrm{~mm}-10 \%$.

U drugom delu tabele 2 za grab može se konstatovati sledeće: Od ukupne količine lišća na osnovnoj grančici otpada na prvu sekciju (do $2 \mathrm{~mm}$ ) $3 \%$, na drugu $(2-4 \mathrm{~mm})-10 \%$, na treću $(4-6 \mathrm{~mm})-22 \%$, na četvrtu $(6-8 \mathrm{~mm})-$ $24 \%$ i na petu $(8-10 \mathrm{~mm})-41 \%$.

Od ukupne količine grančica sa korom debljine do $2 \mathrm{~mm}$ odpada na prvu sekciju - 7\%, na drugu - 7\%, na treću - $19 \%$, na četvrtu - $27 \%$ i na petu - 40\%; grančica sa korom debljine od 2-4 mm ima u drugoi sekciji - 15\%, u trećoj - 13\%, u četvrtoj - 33\% i u petoj - 39\%; grančice sa korom debljine 4-6 mm ima u trećoi sekciji - 46\%, u četvrtoj - $26 \%$ i u pełoj sekciji - $28 \%$; grančica sa korom debljine $6-8 \mathrm{~mm}$ ima u četvrtoj sekciji - $63 \%$ i u petoj - $37 \%$; grančica sa korom debljine $8-10 \mathrm{~mm}$ ima samo u petoj sekciji i iznosi - $100 \%$.

Uzimajući u obzir težinu cele osnovne grančice ukupna težina prve sekcije (do $2 \mathrm{~mm}$ ) iznosi $2 \%$, druge sekcije $(2-4 \mathrm{~mm})-8 \%$, treće sekcije $(4-6 \mathrm{~mm})-17 \%$, četvrte sekcije $(6-8 \mathrm{~mm})-31 \%$ i pete sekcije $(8-10 \mathrm{~mm})-42 \%$.

$\mathrm{Na}$ isti način kao za grab se može izvršiti analiza struktumog sastava drvnog zelenila i za ostale vrste drveća. Ali tim putem ne mislimo poći dalje, nego ćemo analizu za ostale vrste drveća izvršiti u sažetijem obimu.

Za beli jasen: Od ukupne težine druge sekcije (prvu sekciju jasen nema) osnovne grančice odpada na lišće $81 \%$ a ostatak od $19 \%$ na grančice sa korom, treće sekcije - $66 \%$ na lišce a $34 \%$ na grančice sa koroni, četvrte sekcije - $50 \%$ na lišće a $50 \%$ na grančice sa korom i pete sekcije - $48 \%$ na lišće a $52 \%$ na grančice sa korom. U odnosu na težinu cele osnovne grančice odpada na 
Iišće $54 \%$, na grančice sa korom od $2 \mathrm{~mm}$ deblijine - $1 \%$, od $2-4 \mathrm{~mm}-10 \%$,od $4-6 \mathrm{~mm}-14 \%$, od $6-8 \mathrm{~mm}-11 \% \mathrm{i}$ od $8-10 \mathrm{~mm}-10 \%$.

U odnosu na ukupnu težinu lišća odpada na drugu sekciju $-9 \%$, treću - $23 \%$, čełvrtu - $50 \%$ i petu - $46 \%$.

Uzimajući u obzir težinu cele osnovne grančice (lišće i gran. čice) proizlazi iz tabele 2 (II deo) da na ukupnu težinu druge sekcije odpada $6 \%$ treće sekcije $19 \%$, četvrte sekcije $24 \%$ i pete sekcije - $51 \%$.

Za crnu topolu: Od ukupne težine druge sekcije (prva sekcija ne postoji) osnovne grančice odpada na lišće $70 \%$, a ostatak od $30 \%$ na grančice sa korom, treće sekcije - $62 \%$ na lišće a $38 \%$ na grančice sa korom, četvrte sekcije - $53 \%$ na lišće a $47 \%$ na grančice sa korom i pete sekcije - $44 \%$ na lišće, a na lišće $56 \%$ na grančice sa korom. U odnosu na težinu cele osnovne grančice odpada na lišće - 52\%, na grančice sa korom do $2 \mathrm{~mm}$ debljine - $3 \%$, od $2-4 \mathrm{~mm}-12 \%$, od $4-6 \mathrm{~mm}-13 \%$, od $6-8 \mathrm{~mm}-10 \%$ i od $8-10 \mathrm{~mm}-10 \%$.

$U$ odnosu na ukupnu težinu lišća odpada na drugu sekciju $10 \%$, treću - $23 \%$, četvrtu - $32 \%$ i petu - $35 \%$.

Uzimajući u obzir težinu cele osnovne grančice (lišće $i$ grančice) proizlazi iz tabele 2 (II deo) da na ukupnu težinu druge sekcije odpada $7 \%$, treće sekcije - 19\%, četvrte sekcije - $32 \%$ i pete sekcije - $42 \%$.

Za belu vrbu: Od ukupne težine prve sekcije osnovne grančice odpada na lišće $78 \%$, a ostatak od $22 \%$ na grančice sa korom, druge sekcije $69 \%$ na lišće a $31 \%$ na grančice sa korom, treće sekcije - $63 \%$ na lišće a $37 \%$ na grančice sa korom, četvrte sekcije - $37 \%$ na lišće a $63 \%$ na grančice sa korom i pete sekcije - $48 \%$ na lišće a $52 \%$ na grančice sa korom. $U$ odnosu na težinu cele osnovne grančice odpada na lišće $49 \%$, na grančice sa korom od $2 \mathrm{~mm}$ debljine - $3 \%$, od $2-4 \mathrm{~mm}-13 \%$, od $4-6 \mathrm{~mm}-12 \%$, od $6-8 \mathrm{~mm}-9 \%$ i od $8-10 \mathrm{~mm}-14 \%$.

$U$ odnosu na ukupnu težinu lišća odpada na prvu sekciju - $2 \%$, drugu - $7 \%$, treću - $23 \%$, četurtu - $22 \%$ i pełu - $46 \%$. 
Uzimajući u obzir težinu cele osnovne grančice (lišće $i$ grančice) proizlazi iz tabele 2 (II deo) da na ukupnu težinu prve sekcije odpada $1 \%$, druge sekcije $5 \%$, treće sekcije $18 \%$, četvrte sekcije $29 \%$ i pete sekcije $47 \%$.

Za gorski brest: Od ukupne težine prve sekcije osnovne grančice odpada na lišće $90 \%$ a ostatak od $10 \%$ na grančice sa korom, druge sekcije - $81 \%$ na lišće a $19 \%$ na grančice sa korom, treće sekcije - $68 \%$ na lišće a $32 \%$ na grančice sa korom, četvrte sekcije - $63 \%$ na lišće a $37 \%$ na grančice sa korom i pete sekcije - $51 \%$ na lišće a $49 \%$ na grančice sa korom. U odnosu na težinu cele osnovne grančice odpada na lišće $61 \%$, na grančice sa korom od $2 \mathrm{~mm}$ debljine $-3 \%$, od 2-4 mm debljine - $9 \%$, od $4-6 \mathrm{~mm}$ debljine - $8 \%$, od $6-8 \mathrm{~mm}$ debljine - $9 \%$ i od $8-10 \mathrm{~mm}$ deblijine - $10 \%$.

U odnosu na ukupnu težinu lišća odpada na prvu sekciju - $3 \%$, drugu $-10 \%$, treću - $19 \%$, četvrtu - $33 \%$ i pełu - $35 \%$.

Uzimajući u obzir težinu cele osnovne grančice (lišće i grančice) proizlazi iz tabele 2 (II deo) da na ukupnu težinu prve sekcije odpada $2 \%$, druge sekcije $8 \%$, treće sekcije $17 \%$, četvrte sekcije $31 \%$ i pete sekcije $42 \%$.

Za mleč: Od ukupne težine druge sekcije (prva sekcija ne postoji) osnovne grančice odpata na lišće $79 \%$, a ostatak od $21 \%$ na grančice sa karom, treće sekcije - $70 \%$ na lišće a $30 \%$ na grančice sa korom, četvrte sekcije $-57 \%$ na lišće a $43 \%$ na grančice sa korom i pete sekcije - $54 \%$ na lišće a $46 \%$ na grančice sa korom. U odnosu na težinu cele osnovne grančice odpada na lišće $59 \%$, na grančice sa korom do $2 \mathrm{~mm}$ debljine $-2 \%$, od $2-4 \mathrm{~mm}$ debljine $-7 \%$, od $4-6 \mathrm{~mm}$ debljine - $13 \%$, od $6-8 \mathrm{~mm}$ deblijine - $9 \%$ i od $8-10 \mathrm{~mm}$ debliine - $10 \%$.

U odnosu na ukupnu težinu lišća odpada na drugu sekciju $-9 \%$, treću - $21 \%$, četurtu - $26 \%$ i petu - $44 \%$.

Uzimajući u obzir težinu cele osnovne grančice (lišće $\mathbf{i}$ grančice) proizlazi iz tabele 2 (II deo) da na ukupnu težinu druge sekcije odpada $7 \%$, treće sekcije $17 \%$, četvrte sekcije $28 \%$ i pete sekcije $48 \%$. 
Za brezu: Od ukupne težine prive sekcije osnovne grančice odpada na lišće $76 \%$ a ostatak od $24 \%$ na grančice sa korom, druge sekcije - $64 \%$ na lišće a $36 \%$ na grančice sa korom, treće sekcije - $53 \%$ na lišće a $47 \%$ na grančice sa korom, četvrte sekcije - $45 \%$ na lišće a $55 \%$ na grančice sa korom $\mathrm{i}$ pete sekcije - $33 \%$ na lišće a $67 \%$ na grančice sa korom. U odnosu na težinu cele osnovne grančice odpada na lišće $46 \%$, na grančice sa korom do $2 \mathrm{~mm}$ debljine $-5 \%$, od 2-4 mm deblijine - 15\%, od $4-6 \mathrm{~mm}$ debljine - $10 \%$, od $6-8 \mathrm{~mm}$ debljine $-10 \%$ i od $8-10 \mathrm{~mm}$ debljine $-14 \%$.

U odnosu na ukupnu težinu lišća odpada na prvu sekciju $-2 \%$ drugu - $11 \%$, treću - 19\%, četvrtu - $32 \%$ i pełu - $36 \%$.

Uzimajući u obzir težinu cele osnovne grančice (lišće i grančice) proizlazi iz tabele 2 (II deo) da na ukupnu težinu prve sekcije odpada 1\%, druge sekcije $8 \%$, treće sekcije $17 \%$, četvrte sekcije $32 \%$ i pete sekcije $42 \%$.

Za crnu johu: Od ukupne težine prve sekcije osnovne grančice odpada na lišće $85 \%$ a ostatak od $15 \%$ na grančice sa korom, druge sekcije $73 \%$ na lišće a $27 \%$ na grančice sa korom, treće sekcije - $51 \%$ na lišće a $49 \%$ na grančice sa korom, četvrte sekcije - $53 \%$ na lišće a $47 \%$ na grančice sa korom $i$ pete sekcije - $46 \%$ na lišće a $54 \%$ na grančice sa korom. U odnosu na težinu cele osnovme grančice odpada na lišće $51 \%$, na grančice sa korom do $2 \mathrm{~mm}$ debljine $-5 \%$, od 2-4 mm debljine - $11 \%$, od $4-6 \mathrm{~mm}$ debljine - $13 \%$, od $6-8 \mathrm{~mm}$ debljine - $9 \%$, i od $8-10 \mathrm{~mm}$ debljine $-11 \%$.

U odnosu na ukupnu težinu lišća odpada na prvu sekciju - $3 \%$, drugu - $12 \%$, treću - 15\%, četurtu - $29 \%$ i pełu - $41 \%$.

Uzimajući u obzir težinu cele osnovne grančice (lišćce i grančice) proizlazi iz tabele 2 (II deo) da na ukupnu težinu prve sekcije odpada $2 \%$, druge sekcije $8 \%$, treće sekcije $16 \%$, četvrte sekcije $28 \%$ i pete sekcije $46 \%$.

Analizom tabela 1 i 2 mogu se izvesti sledeći zaključci:

1. Uzimajući u obzir strukturu grančica sa korom po debljini u sekcijama osnovne grančice od $10 \mathrm{~mm}$ debljine, može se izvesti zaključak, da se u drvnom zelenilu svih osam vrsti lišćara pojavljuju i grančice od $2 \mathrm{~mm}$ debljine. 
U odnosu na ukupnu težinu osnovne gračice najviše imaju grančica do $2 \mathrm{~mm}$ debljine breza i grab sa po $24 \%$, zatim dolaze vrba, joha, brest.

2. Prema ukupnoj težini osnovne grančice od $10 \mathrm{~mm}$ debljine na prvom mestu dolazi vrba $(167,72 \mathrm{gr})$, zatim javor $(161,42 \mathrm{gr})$, breza $(160,12 \mathrm{gr})$, grab $(153,33 \mathrm{gr})$, jasen $(153,30 \mathrm{gr})$, brest $(147,26 \mathrm{gr})$, joha $(136,28 \mathrm{gr}) \mathbf{i}$ topola $(134,15 \mathrm{gr})$.

3. Najviše lišća ima na osnovnoj grančici od $10 \mathrm{~mm}$ debljine, mereno u naturalnim pokazateljima, javor $(95,00 \mathrm{gr})$, zatim brest $(89,25 \mathrm{gr})$, grab $(83,34 \mathrm{gr})$, jasen $(82,95 \mathrm{gr})$, vrba $(81,69 \mathrm{gr})$, breza $(73,45 \mathrm{gr})$, joha $(70,12 \mathrm{gr})$ i topola $(69,99 \mathrm{gr})$.

4. Najviše kore ima na osnovnoj grančici od $10 \mathrm{~mm}$ deblijine, mereno u naturalnim pokazateljima, breza $(37,20 \mathrm{gr})$, zatim topola $(33,35 \mathrm{gr})$, vrba $(30,27 \mathrm{gr})$, jasen $(27,25 \mathrm{gr})$, joha $(26,20 \mathrm{gr})$, brest $(26,62 \mathrm{gr})$, javor $(23,81 \mathrm{gr}) \mathrm{i}$ grab $(19,39 \mathrm{gr})$.

5. Najviše drveta ima na osnovnoj grančici do $10 \mathrm{~mm}$ debljine, mereno u naturalnim pokazateljima, breza $(45,36 \mathrm{gr})$ zatim grab $(37,60 \mathrm{gr})$, javor $(33,84 \mathrm{gr})$, joha $(31,75 \mathrm{gr})$, vrba $(28,66 \mathrm{gr})$, jasen $(27,37 \mathrm{gr})$, brest $(25,96 \mathrm{gr})$ i topola $(17,27 \mathrm{gr})$.

6. Kod svih osam vrsti liščara nalażj se najveća količina lišća u prve četiri sekcije, tj. do debljine osnovne grančice $6 \mathrm{~mm}$. Na svim ovim sekcijama nalazi se lišća preko $50 \%$ od ukupne težine sekcije.

Poznavajući težinske $\mathrm{i}$ strukturne odnose u drvnom zelenilu, formiranom od grančica do $10 \mathrm{~mm}$ debljine, izmedju lišća, kore i drveta potrebno je za praktično iskorišćavanje ove sirovine. Ova saznanja omogućavaju da se za svaku sekciju ili više sekcija osnovne grančice, odredi učešče lišća, kore i drveta a time i količine fiziološki aktivnih materija u koncentratu, odnosno vitaminsko-mineralnom brašnu kao finalnom proizvodu.

Savremena tehnologija prerade drvnog zelenila omogućava da se iz drvnog zelenila izdvaja za preradu samo lišće ili lišće i grančice do željenih debljina, uzimajući $10 \mathrm{~mm}$ za najveću debljinu. To znači da se učešce celuloze 
u koncentratu može regulisati a takodje $\mathbf{i}$ količina fiziološki aktivnih máterija, odnosno da se iz koncentrata što više eliminiše učešce celuloze kao balasta. To drugim rečima znači da se drvno zelenilo može formirati samo od lišća (četina) ili od lišća (četina) i grančica do debljine od 10, 8, 6, 4 i $2 \mathrm{~mm}$.

\subsection{Proučavanje hemijskog sastava drvnog zelenila}

Proučavanje hemijskog sastava drvnog zelenila vršeno je posebno za sva tri njegova sastavna dela, ti. posebno za lišće, posebno za koru i posebno za drvo.

U drvnom zelenilu ćemo istraživati količine sledećih grupa fiziološki aktivnih materija: vitamine, mikro elemente $i$ ostale materije.

\subsection{Vitamini}

O vitaminima i njihovom značaju za ljude $i$ životinje opšimije je izloženo u ediciji, koja je ranije objavljena. Iz ovog razloga ograničićemo se da na ovom mestu pokažemo samo rezultate izvršenih istraživanja.

$U$ lišću, kori i drvetu istražene su količine sledećih vitamina: karotin, kao provitamin A, zatim vitamin $\mathrm{C}, \mathrm{B}_{2} \mathrm{~K}$ i E.

\subsection{Karotin - provitamin A mg u kg suve materije}

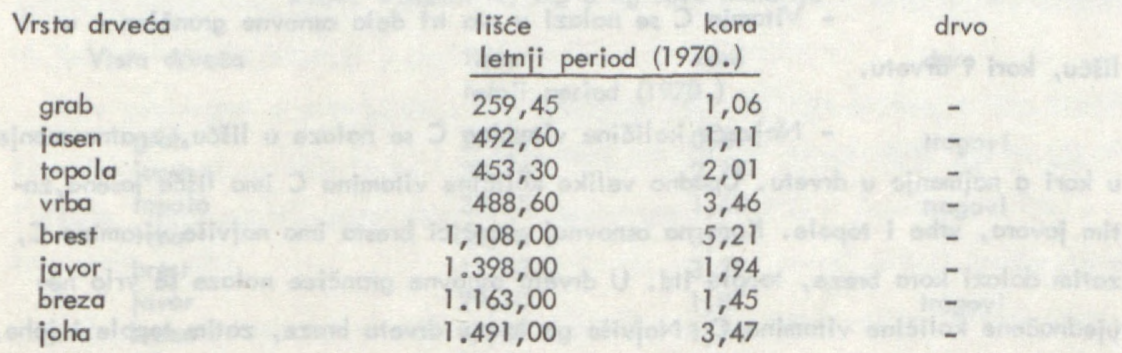

deće konstatacije:

Iz priloženih podataka o količini karotina mogu se izvesti sle- 
- U lišću svih proučavanih vrsta šumskog drveća nalaze se najveće količine karotina. Naročito se velike količine nalaze u listu johe, zatim javora, breze i bresta. Znamo manje, ali još uvek vrlo velike, količine karotina nalaze se u prve četiri vrste lišćara iz prednje tabele.

- U kori osnovne grančice nalaze se vrlo male količine karotina. Najviše ga ima u kori bresta, zatim johe $\mathbf{i}$ vrbe a najmanje u kori graba.

- U drvetu osnovne grančice svih proučavanih vrsta drveća ne nalazi se karotin.

\subsection{Vitamin C, mg. u $\mathrm{kg}$ suve materije}

\begin{tabular}{llrr} 
Vrsta drveća & \multicolumn{1}{l}{$\begin{array}{l}\text { lišće } \\
\text { lełnji period }\end{array}$} & \multicolumn{1}{c}{$\begin{array}{c}\text { kora } \\
(1970)\end{array}$} \\
\cline { 2 - 4 } grab & $1.107,89$ & 164,08 & 41,18 \\
jasen & $8.653,85$ & 121,60 & 62,78 \\
topola & $3.093,04$ & 572,09 & 367,76 \\
vrba & $4.172,32$ & 262,02 & 113,35 \\
brest & $2.173,10$ & 819,52 & 151,88 \\
javor & $5.552,52$ & 506,30 & 36,48 \\
breza & $2.275,94$ & 691,49 & 435,48 \\
joha & $1.351,15$ & 478,40 & 243,76
\end{tabular}

Iz priloženih podataka o količini vitamina $C$, mogu se izvesti sledeće konstatacije:

- Vitamin C se nalazi u sva tri dela osnovne grančice - u lišću, kori i drvetu.

- Najveće količine vitamina C se nalaze u lišću, znatno manje u kori a najmanje u drvetu. Upadno velike količine vitamina C ima lišce jasena,zatim javora, vrbe $\mathbf{i}$ topole. Kora na osnovnọ grančici bresta ima najviše vitamina $C$, zatim dolazi kora breze, topole itd. U drvetu osnovne grančice nalaze se vrlo neyjednačene količine vitamina C. Najviše ga ima u drvetu breze, zatim topole i johe, upadno manje $u$ drvetu graba $i$ javora a naročito male količine $u$ drvetu jasena, koji 
ima u listu, kao što je nap̣red istaknuto, $n$ ajviše vitamina $C$.

\subsection{Vitamin $\mathrm{B}_{2}, \mathrm{mg} \cup \mathrm{kg}$ suve materije}

$\begin{array}{llcr}\text { Vrsta drveća } & \text { lišće } & \begin{array}{c}\text { kora } \\ \text { letnji period } \\ (1970 .)\end{array} & \text { drvo } \\ \text { grab } & 18,43 & 2,35 & \text { - } \\ \text { jasen } & 25,99 & 4,43 & - \\ \text { topola } & 13,27 & 1,80 & - \\ \text { vrba } & 17,94 & 1,87 & - \\ \text { brest } & 7,58 & 1,20 & - \\ \text { javor } & 10,98 & 1,38 & - \\ \text { breza } & 17,14 & 1,83 & - \\ \text { joha } & 17,42 & 1,90 & -\end{array}$

Iz priloženih podataka okoličini vitamina $B_{2}$ mogu se izvesti sledeće konstatacije:

- Vitamina $B_{2}$ (riboflavina) ima samo u lišću i kori osnovne grančice kod proučavanih vrsta drveća, dok ga u drvetu nema.

- Najviše vitamina $B_{2}$ se nalazi u lišću i kori jasena,zatim graba, vrbe, breze $\mathrm{i}$ johe $\mathrm{i}$ najmanje u lišću $\mathrm{i}$ kori bresta.

- Veću količinu vitamina $B_{2} \cup$ lišću prati $\mathbf{i}$ veća količina istog

vitamina u kori.

2.54. Vitamin $\mathrm{K}, \mathrm{mg}$ u $\mathrm{kg}$ suve materije

$\begin{array}{llcc}\text { Vrsta drveća } & \text { lišće } & \begin{array}{c}\text { kora } \\ \text { letnji period } \\ (1970 .)\end{array} & \text { drvo } \\ \text { grab } & 27,15 & 0,89 & \text { tragovi } \\ \text { jasen } & 30,16 & 2,15 & - \\ \text { topola } & 33,55 & 1,60 & \text { tragovi } \\ \text { vrba } & 22,98 & 3,22 & - \\ \text { brest } & 19,53 & 3,29 & - \\ \text { javor } & 29,10 & 1,87 & \text { tragovi } \\ \text { breza } & 17,31 & 1,14 & - \\ \text { joha } & 22,58 & 1,13 & -\end{array}$


sledeće konstatacije:

lz priloženih podataka o količini vitamina $\mathrm{K}$ mogu se izvesti

- Vitamin K se nalazi uglavnom u lišcu i kori, dok ga u drvetu ima samo $u$ tragovima $i$ to samo kod nekih vrsta (grab, topola javor) a $u$ ostalim vrstama drveća ga nema.

- U lišcu ima najviše vitamina $K$ topola, zatim slede jasen, grab, vrba, joha i brest.

- U kori osnovne grančice bresta, vrbe $\mathrm{i}$ jasena nalaze se najveće količine vitamina $K$. Ove iste vrste imaju u lišču najmanje količine ovog vitamina.

2.55. Vitamin $E, m g ~ v g$ suve materije

$\begin{array}{clcl}\text { Vrsta drveća } & \begin{array}{l}\text { lišće } \\ \text { letnji period }\end{array} & \begin{array}{c}\text { kora } \\ (1970 .)\end{array} & \text { drvo } \\ \text { grab } & 182,9 & \text { tragovi } & \text { tragovi } \\ \text { jasen } & 340,8 & 137,0 & \text { tragovi } \\ \text { topola } & 298,2 & 121,2 & \text { tragovi } \\ \text { vrba } & 497,5 & 84,1 & \text { tragovi } \\ \text { brest } & 472,8 & 108,0 & \text { tragovi } \\ \text { javor } & 521,9 & 180,7 & \text { tragovi } \\ \text { breza } & 578,0 & \text { tragovi } & \text { tragovi } \\ \text { joha } & 216,0 & 133,7 & \text { tragovi }\end{array}$

Iz priloženih podataka o količini vitamina $E$ mogu se izvesti sledeće konstatacije:

- Vitamin E se u glavnom nalazi u lišću; u kori ga većina drveća ima u znatnoj količini, dok ga grab i breza imaju samo u tragovima; $u$ drvetu ga sve vrste drveća imaju samo u tragovima.

- U lišću imaju vitamin E najviše breza, zatim javor, vrba i brest, potom sleduju jasen, topola, joha i grab.

- U kori imaju vitamin E najviše javor, zatim jasen $i$ joha, potom sleduju topola, brest $i$ vrba, dok ga grab $i$ breza imaju u tragovima. 


\subsection{Mikroelementi}

Od mikroelemenata proučavanjima smo obuhvatili: železo

$(\mathrm{Fe})$, mangan $(\mathrm{Mn})$, cink ( $\mathrm{Zn})$, kobalt (Co), molibden (Mo) i bakar (Cu). Količinu mikroelemenata u lišću, kori $i$ drvetu pokazaćemo na isti način kao $i$ vitamine.

\subsection{1. Železo (Fe) $\mathrm{mg} \mathrm{u} \mathrm{kg}$ suve materije}

Letnii period (1970.)

\begin{tabular}{cccr} 
Vrsta drveća & \multicolumn{1}{c}{ lišće } & \multicolumn{1}{c}{ kora } & \multicolumn{1}{c}{ drvo } \\
grab & 50,50 & 40,09 & 45,20 \\
jasen & 431,50 & 124,00 & 61,04 \\
topola & 317,00 & 324,00 & 256,60 \\
vrba & 124,00 & 22,85 & 65,41 \\
brest & 420,40 & 573,10 & 466,90 \\
javor & 540,20 & 180,10 & 37,70 \\
breza & 342,10 & 131,70 & 127,90 \\
joha & $1.130,00$ & 346,00 & 49,18
\end{tabular}

Iz priloženih podataka o količini železa mogu se izvesti sle-

deće konstatacije:

- Železo (Fe) se nalazi u sva tri dela drvnog zelenila - listu,

kori i drvetu.

- U. lišću najviše železa ima joha, zatim sleduju sa približno jednakim količinama, javor, jasen $\mathbf{i}$ brest, potom breza $\mathbf{i}$ vrba a upadno malu količinu železa ima list graba.

- U kori osnovne grančice neke vrste drveća imaju veće količine železa nego u lišću (brest $i$ topola). Najviše železa u kori imaju brest, joha i topola, zatim sleduju javor, breza $\mathbf{i}$ jasen, najmanja količiñ železa se nalazi u kori graba $i$ vrbe.

- U drvetu osnovne grančice ima upadno velike količine železa brest, topola i breza a znatno manje vrba, jasen, joha, grab i javor. 
2.62. Mangan. Mn, mg u kg suve materije lemii period (1970.)

\begin{tabular}{lrlr} 
Vrsta drveća & \multicolumn{1}{l}{ lišće } & kora & drvo \\
grab & 400,70 & 317,70 & 77,10 \\
jasen & 59,11 & tragovi & 57,35 \\
topola & 81,66 & 135,30 & 126,30 \\
vrba & 73,20 & 254,30 & tragovi \\
brest & 41,50 & tragovi & tragovi \\
javor & 179,40 & 139,60 & 78,70 \\
breza & 106,50 & 584,60 & 40,66 \\
joha & 185,50 & 202,10 & 142,80
\end{tabular}

Iz priloženih podataka o količini mangana mogu se izvesti sledeće konstatacije:

- Mangan $(\mathrm{Mn})$ se nalazi u sva tri dela drvnog zelenila - lišću, kori i drvetu, s tim što se u kori nekih vrsta drveća (jasen, brest) nalazi u tragovima a u drvetu vrbe $i$ bresta takodje u tragovima.

- U lišcu graba ima mangana znatno više od ostalih vrsta drveca; zatim sleduju joha, javor i breza a upadno manje ga imaju topola, vrba i brest.

- U kori osnovne grančice neke vrste drveća imaju znatno veće količine mangana nego $v$ listu a neke ga u kori imaju u tragovima. Breza ima najveće količine mangana u kori, zatim sleduju grab $\mathbf{i}$ joha, potom topola $\mathbf{i}$ javor.

- U drvetu osnovne grančice johe $i$ topole ima najviše mangana; zatim sleduju javor, grab, jasen i breza. 
2.63. Cink $\mathrm{Zn}, \mathrm{mg}$ u $\mathrm{kg}$ suve materije Letnji period (1970.)

$\begin{array}{clll}\text { Vrsta drveća } & \text { lišće } & \text { kora } & \text { drvo } \\ \text { grab } & 117,92 & 54,30 & 12,72 \\ \text { jasen } & 183,81 & 90,00 & 68,32 \\ \text { topola } & 134,55 & 21,32 & 11,05 \\ \text { vrba } & 138,73 & 19,72 & 15,33 \\ \text { brest } & 180,20 & 46,05 & 35,02 \\ \text { javor } & 112,58 & 80,31 & 12,54 \\ \text { breza } & 154,87 & 43,27 & 18,61 \\ \text { joha } & 147,15 & 32,38 & 15,73\end{array}$

Iz priloženih podataka o količini cinka mogu se izvesti sledece konstatacije:

- Cink $(Z n)$ se nalazi u sva tri dela osnovne grančice - lišću,

kori i drvetu.

- U lišću se nalaze približno jednake količine cinka; znatno manje, a medjusobom približno jednake, količine cinka nalaze se i u kori kao i u drvetu.

- Upadno veće količine cinka nalaze se u kori jasena $i$ javora, a u drvetu - jasena $\mathrm{i}$ bresta.

2.64. Kobalt Co, mg $u \mathrm{~kg}$ suve materije Lemii period (1970.)

\begin{tabular}{lrrr} 
Vrsta drveća & \multicolumn{1}{c}{ lišće } & kora & \multicolumn{1}{c}{ drvo } \\
grab & 33,55 & 30,77 & 41,24 \\
jasen & 39,90 & 33,45 & 25,83 \\
topola & 5,21 & 5,53 & 3,82 \\
vrba & 4,10 & 5,02 & 1,97 \\
brest & 49,88 & 42,25 & 38,76 \\
javor & 7,90 & 19,00 & 24,15 \\
breza & 10,65 & 4,55 & 9,10 \\
joha & 25,83 & 12,40 & 27,83
\end{tabular}


Iz priloženih podataka o količini kobalta mogu se izvesti sledeće konstatacije:

- Kobalt (Co) se nalazi u približno jednakim količinama u sva tri dela osnovne grančice - lišću, kori i drvetu.

- Male količine kobalta se nalaze u lišću, kori i drvetu topole $i$ vrbe, ti. vrsta drveća koje rastu na jako vlažnim zemljištu, što nije slučaj i sa johom.

- U lišću jasena, bresta, breze i johe nalaze se najveće količine kobalta; zatim sleduju sa znatno manjim količinama ostale vrste drveća.

- U kori osnovne grančice imaju najviše kobalta brest, jasen i grab a najmanje breza, vrba i topola.

- U drvetu osnovne grančice se nalaze kod nekih vrsta drveca velike količine kobalta, kao i u lišcu i kori. Najviše ga ima u drvetu graba, bresta, zatim johe $\mathrm{i}$ jasena a najmanje $u$ drvetu vrbe $\mathrm{i}$ topole.

2.65. Molibden Mo, $\mathrm{mg}$ u $\mathrm{kg}$ suve materije Letnii period (1970.)

Vrsta drveca
grab
jasen
topola
vrba
brest
javor
breza
joha

$\begin{array}{lll}\text { lišće } & \text { kora } & \text { drvo } \\ 0,428 & 0,374 & 0,111 \\ 0,395 & 0,174 & 0,098 \\ 0,521 & 0,278 & 0,154 \\ 0,593 & 0,412 & 0,231 \\ 0,293 & 0,119 & 0,072 \\ 0,452 & 0,214 & 0,108 \\ 0,253 & 0,117 & 0,085 \\ 0,284 & 0,094 & 0,052\end{array}$

Iz priloženih podataka o količini molibdena mogu se izvesti sledeče konstatacije:

- Molibden (Mo) se nalazi u sva tri dela osnovne grančice lišću, kori i drvetu. Najviše ga ima u lišću, nešto manje u kori a najmanje u drvetu. 
- Molibdena ima najviše u lišću vrbe $i$ topole; zatim slede javor, grab $\mathrm{i}$ jasen, a najmanje ga ima u listu bresta, johe $\mathrm{i}$ breze.

- U kori osnovne grančice najviše imaju molibdena: vrba i grab, zatim topola i javor, a najmanje ga ima u kori jasena, bresta, breze a naročito johe.

- U drvetu osnovne grančice najviše imaju molibdena vrba, topola, grab i javor; zatim jasen, breza, brest $\mathbf{i}$ joha.

2.66. Bakar. $\mathrm{Cu}, \mathrm{mg}$ u $\mathrm{kg}$ suve materije Letnji period (1970.)

$\begin{array}{crrr}\text { Vrsta drveća } & \text { lišće } & \text { kora } & \text { drvo } \\ \text { grab } & 3,46 & 2,57 & 1,57 \\ \text { jasen } & 3,27 & 4,25 & 8,22 \\ \text { topola } & 2,82 & 3,02 & 2,37 \\ \text { vrba } & 20,80 & 2,62 & 2,03 \\ \text { brest } & 1,85 & 2,93 & 7,51 \\ \text { javor } & 2,33 & 2,63 & 7,62 \\ \text { breza } & 4,13 & 2,59 & 2,24 \\ \text { joha } & 2,31 & 3,39 & 6,24\end{array}$

Iz priloženih podataka o količini bakra mogu se izvesti sledeće konstatacije:

- Bakar (Cu) se nalazi u sva tri dela osnovne grančice - lišću, kori i drvetu $i$ to u približno jednakim količinama.

- U lišću vrbe se nalaze upadno veća količina bakra, u odnosu na ostale vrste drveća; zatim ga imaju znatno manje lišće breze, graba $i$ jasena, potom slede topola, joha $\mathbf{i}$ javor, a najmanje ga ima list bresta.

- U kori osnovne grančice imaju približno jednake količine bakra sve proučavane vrste drveća. Najveće količine se nalaze u kori jasena, zatim johe, topole $\mathrm{i}$ bresta, a najmanje ga imaju javor, breza $\mathrm{i}$ vrba. 
- U drvetu osnovne grančice se nalaze, u odnosu prema listu i kori, znatne količíne bakra. Najviše ga ima drvo jasena, zatim javora, bresta i johe, a najmanje topola $i$ breza, dok ga grab ima najmanje.

\subsection{Ostale materije u drvnom zelenilu}

U ostale materije u drvnom zelenilu (osnovnim grančicama) obuhvatili smo sledeće: Belančevine, pepeo, vodeni ekstrakt, monosaharide ili monoze, ekstrakt petrol - eterski i hlorofil.

\subsection{Belančevina, u \% suve materije}

Lemii period (1970.)

Vrsta drveća
grab
jasen
topola
vrba
brest
javor
breza
joha

$\begin{array}{lll}\text { lišće } & \text { kora } & \text { drvo } \\ 10,69 & 5,81 & 3,69 \\ 11,06 & 4,56 & 3,38 \\ 13,31 & 3,75 & 3,12 \\ 14,56 & 4,56 & 2,81 \\ 12,94 & 4,25 & 2,69 \\ 12,50 & 5,50 & 3,12 \\ 15,38 & 6,06 & 3,62 \\ 13,19 & 5,00 & 4,00\end{array}$

Iz priloženih podataka o količini belančevine mogu se izvesti sledeće konstatacije:

- Belančevine se nalaze u sva tri dela osnovne grančice u lišću, kori i drvetu. Najviše belančevine ima u lišću, zatim upola manje u kori i upola manje, od količine u kori, u drvetu.

- U lišću svih proučavanih vrsta drveća nalazi se belančevine $u$ približno jednakim količinama; najviše se nalazi u lišču breze $i$ vrbe, zatim topole $\mathbf{i}$ johe.

- U kori osnovne grančice takodje se nalaze približno jednake količine belančevine; najviše se nalazi u kori breze, graba, javora $\mathrm{i}$ johe. 
- U drvetu osnovne grančice nalaze se takodje približno jednake količine belančevine, samo upola manje nego u kori, a naročito u lišću. Najviše belančevine ima drvo johe, zatim graba, breze, jasena i javora.

2.72. Pe p e o, u
$\begin{array}{lll}\text { Letnji period }(1970 .) & & \\ \text { lišće } & \text { kora } & \text { drvo } \\ 0,402 & 0,370 & 0,274 \\ 0,556 & 0,362 & 0,242 \\ 0,736 & 0,349 & 0,231 \\ 0,601 & 0,624 & 0,196 \\ 0,314 & 0,123 & 0,266 \\ 0,419 & 0,425 & 0,208 \\ 0,184 & 0,214 & 0,164 \\ 0,512 & 0,480 & 0,317\end{array}$

Iz priloženih podataka o količini pepela mogu se izvesti sledeće konstatacije:

- Veće količine pepela nalaze se u lišću, zatim u kori i najzad u drvetu.

- Uzimajući u obzir samo lišće i koru najviše pepela imaju topola i vrba; zatim sleduju jasen, joha, javor $\mathbf{i}$ grab, a potom brest $\mathrm{i}$ breza.

- Drvo osnovne grančice johe, graba, bresta, jasena i topole ima najviše pepela, zatim dolaze javor, vrba $\mathrm{i}$ breza.

2.73. Ekstrakt vodeni, u \% Letnji period (1970.)

$\begin{array}{cllr}\text { Vrsta drveća } & \text { Iišće } & \text { kora } & \text { drvo } \\ \text { grab } & 12,54 & 15,27 & 9,63 \\ \text { jasen } & 18,54 & 19,12 & 14,04 \\ \text { topola } & 17,05 & 18,14 & 15,36 \\ \text { vrba } & 18,15 & 19,72 & 14,44 \\ \text { brest } & 13,14 & 15,80 & 9,34 \\ \text { javor } & 15,17 & 18,06 & 14,85 \\ \text { breza } & 11,16 & 15,27 & 10,65 \\ \text { joha } & 14,25 & 16,42 & 13,89\end{array}$


Iz priloženih podataka o količini ekstrakta vodenog mogu se izvesti sledeće konstatacije:

- Ekstrakt vodeni nalazi se u približno jednakim količinama u sva tri dela drvnog zelenila. Najviše se nalaze u kori, zatim lišću i najzad u drvetu. Vrba, jasen $\mathbf{i}$ topola imaju $\mathbf{i}$ lišću, kori i drvetu veće količine ekstrakta vodenih od ostalih proučavanih vrsta drveća.

\subsection{Monosaharidi ili monoze}

Sadržaj monoza u drvnom zelenilu pokazaćemo u tabeli kao i sve druge materije koje smo do sada prikazali:

$$
\text { Monoze, gr u kg suve materije }
$$

$\begin{array}{lrrr}\text { Vrsta drveća } & \text { lišće } & \text { kora } & \text { drvo } \\ \text { grab } & 2,17 & 3,20 & 4,14 \\ \text { jasen } & 18,14 & 21,63 & 17,05 \\ \text { topola } & 20,07 & 21,63 & 18,31 \\ \text { vrba } & 4,51 & 9,65 & 7,12 \\ \text { brest } & 13,71 & 10,63 & 9,97 \\ \text { javor } & 9,41 & 22,45 & 21,64 \\ \text { breza } & 2,29 & 15,25 & 14,61 \\ \text { joha } & 12,68 & 14,03 & 10,63\end{array}$

deće konstatacije:

Iz priloženih podataka o količini monoza mogu se izvesti sle-

- Monoze se nalaze u sva tri dela osnovne grančice - u lišču,

kori i drvetu.

- Najviše se monoze nalazi u sva tri dela osnovne grančice topole, zatim jasena, javora a najmanje graba.

- U lišću imaju najviše monoze topola, jasen, brest i joha; u kori - javor, jasen i topola, a najmanje grab i vrba; u drvetu - javor, tapola, jasen, a najmanje grab $\mathbf{i}$ brest. 
2.75. Ekstrakt petrol - eterski, u\% Lotnii period (1970.)

$\begin{array}{clll}\text { Vrsta drveca } & \text { lišce } & \text { kora } & \text { divo } \\ \text { grab } & 0,225 & 0,417 & 0,198 \\ \text { jasen } & 0,317 & 0,643 & 0,238 \\ \text { topola } & 0,483 & 0,526 & 0,412 \\ \text { vrba } & 0,461 & 0,752 & 0,396 \\ \text { brest } & 0,381 & 0,4 \mathrm{J3} & 0,258 \\ \text { javor } & 0,311 & 0,351 & 0,284 \\ \text { breza } & 0,142 & 0,348 & 0,129 \\ \text { joha } & 0,401 & 0,483 & 0,316\end{array}$

Iz prilożenih podataka o kolicini okstrakta peirol - oterskih mogu se izvesti sledeće konstatacije:

- Ekstrakt petrol - eterski nalazi se u sva tri dela osnovne grančice - u lišču, kori i drvetu. Največe kolicine se nalaze u kori, zatim u lißçu i najzad u drvetu.

2.76. Hlorofil, mg u $\mathrm{kg}$ suve materije Lotnji poriod (1970.)

\begin{tabular}{clrr} 
Vrsta drveca & \multicolumn{1}{l}{ Irsce } & \multicolumn{1}{c}{ kora } & drvo \\
grab & $25.149,85$ & 737.732 & - \\
jasen & $29.137,82$ & 1.816 .180 & - \\
topola & $14.996,26$ & 706.420 & - \\
vrba & $13.926,89$ & $1.895,460$ & - \\
brest & $23.162,57$ & 382.190 & - \\
javor & $24.489,69$ & 916.780 & - \\
breza & $12.663,14$ & $1.025,470$ & - \\
joha & $28.222,52$ & 811.560 & -
\end{tabular}

Iz priloženth podataka o kollčlnt hlorofila mogu se |zvesłl

sledece konstataclle: 
- Hlorofil se nalazi na osnovnoj grančici samo u lišcu i kori. U kori se nalaze sasvim male količine hlorofila prema količinama koje se nalaze U lišču.

- Najveće količine hlorofila u lišću imaju jasen, joha i grab, zatim javor $\mathrm{i}$ brest a najmanje topola, vrba $\mathrm{i}$ breza.

- Najveće količine hlonfila u kori imaju vrba, jasen $\mathbf{i}$ breza, zatim javor, joha, grab i topola, a ṇ̣jmanje brest.

\subsection{Uporedna tabela rezultata proučavanja drvnog zelenila}

Rezultati proučavanja hemijskog sastava drvnog zelenila za svaku vrstu drveta prikazani su u tabeli 3. Podaci su dati odvojeno za lišće,koru i drvo.

Sva proučavanja drvnog zelenila izvršena su, kao što je napred istaknuto, samo za period leta. Proučavanja bi bila kompletna da su izvršena za sva tri godišnja doba - proleće, leto $i$ jesen $\mathrm{ti}$. za ceo vegetacioni period.

Iz podataka tabele 3 mogu se izvesti sledeće opšte konstatacije:

1. Belančevine se nalaze u sva tri dela osnovne grančice, $i$ to upadno više u lišču, zatim znatno manje u kori $i$ najmanje $u$ drvetu.

2. Karotina, kao fiziološki najvažnijeg sastavnog dela drvnog zelenila, ima samo u lišću $\mathbf{i}$ kori. $U$ lišću se nalaze najveće količine karotina, dok ga u kori ima u sasvim malim količinama, tako da bi se mogao i zanemariti. Značajno je istaći da su pronadjene naročito velike količine karotina u lišću johe, javora, bresta $\mathrm{i}$ breze.

3. Hlorofil se nalazi samo u lišću i kori. U lišću ga ima najviše a u kori neznatno. Najviše ga ima u lišću jasena, zatim johe, graba itd.

4. Vitamini $C, B_{2}, K$ i E se nalaze u lišcu $i$ kori $i$ to najviše u lišču, zatim upadno manje u kori. $U$ drvetu ih ima veoma malo $i$ to $u$ tragovima ili ih vopšte nema. 


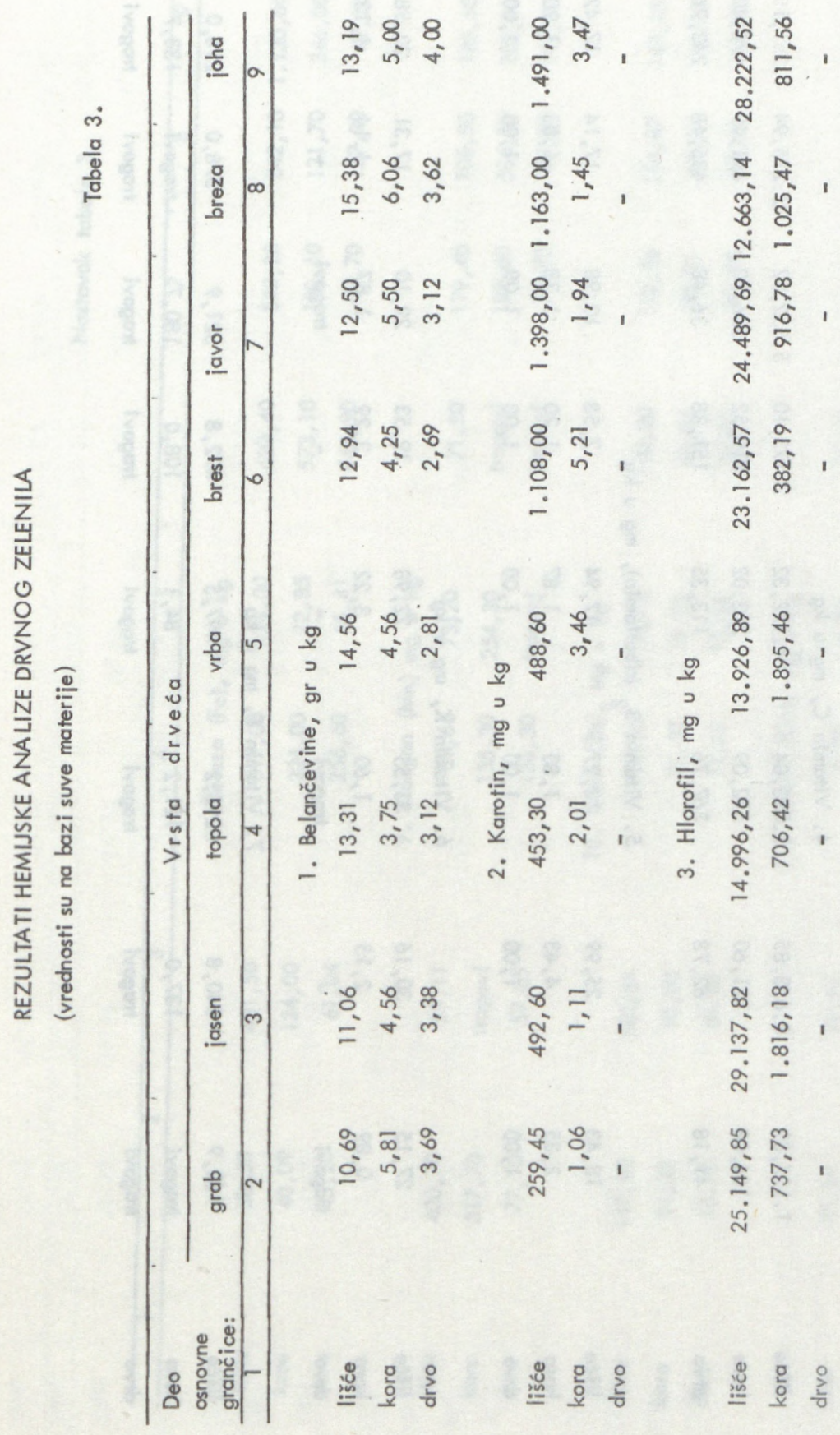




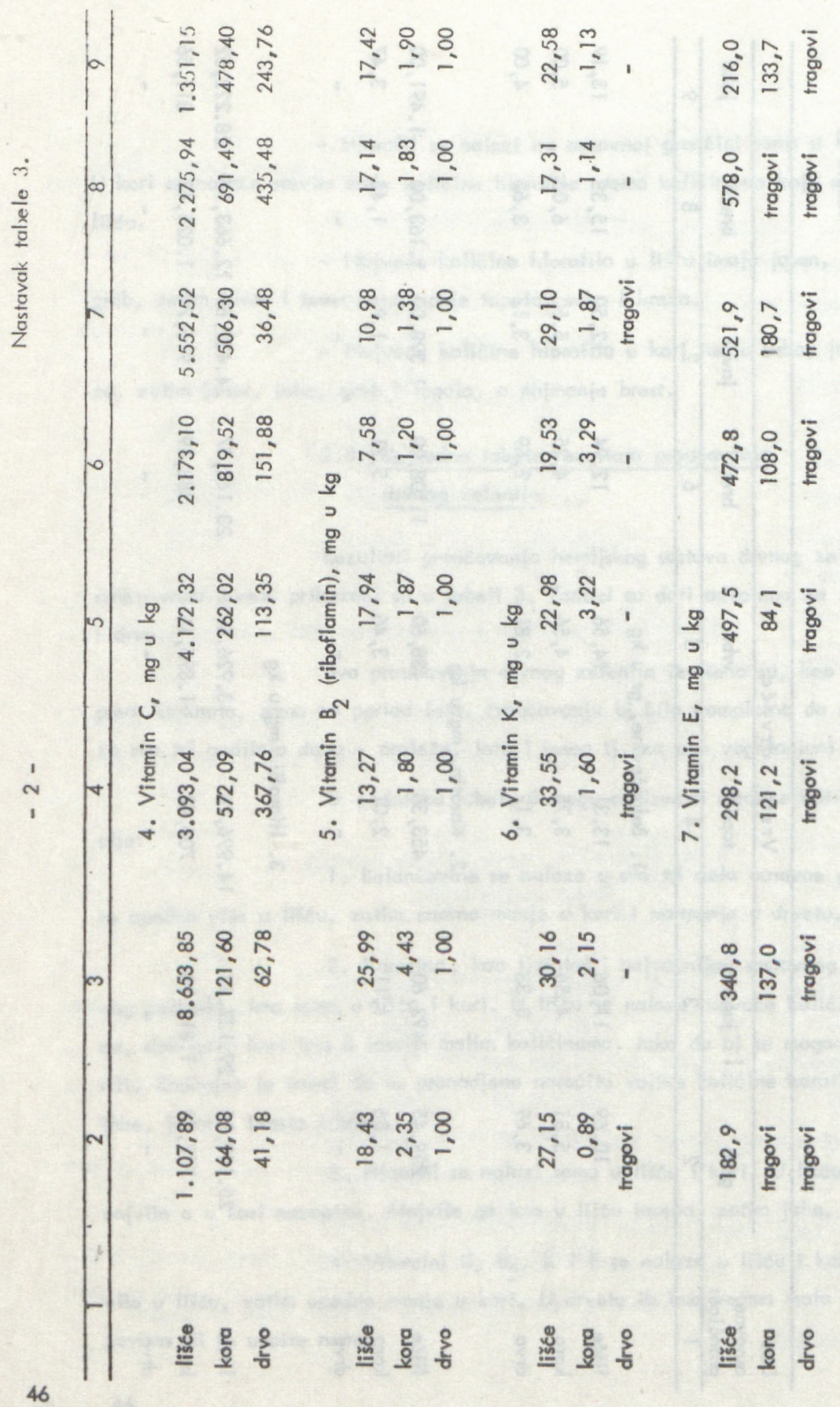




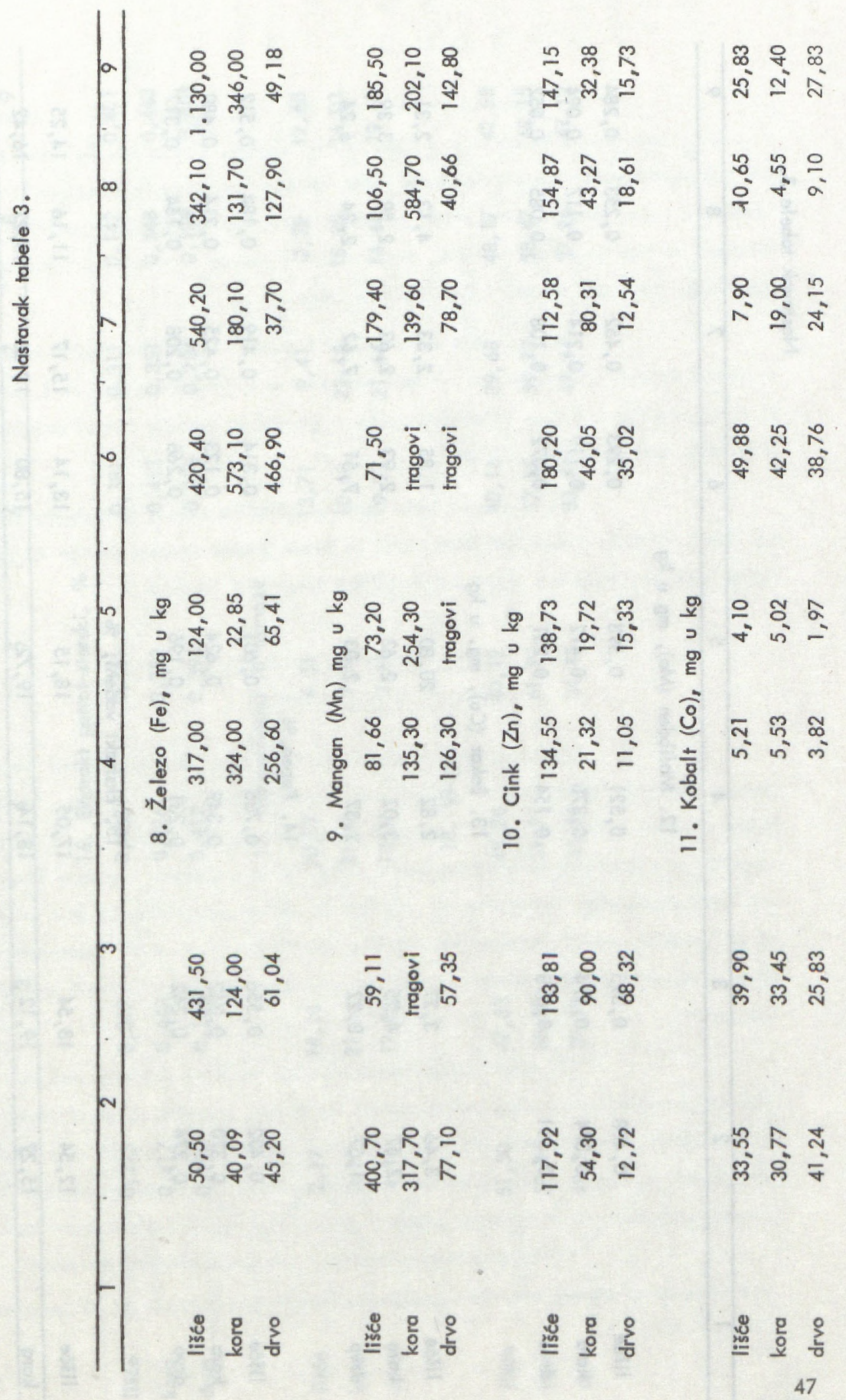




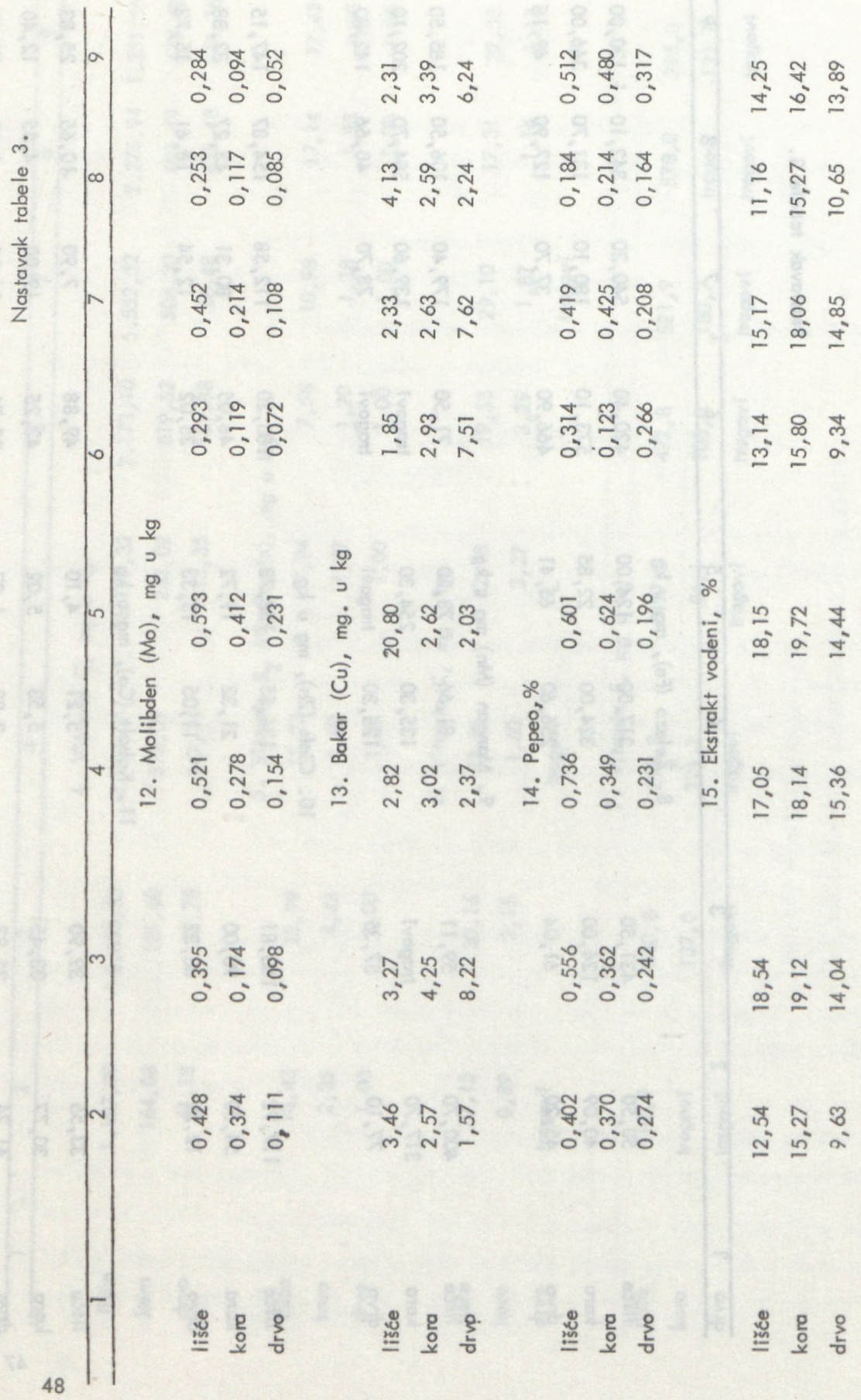




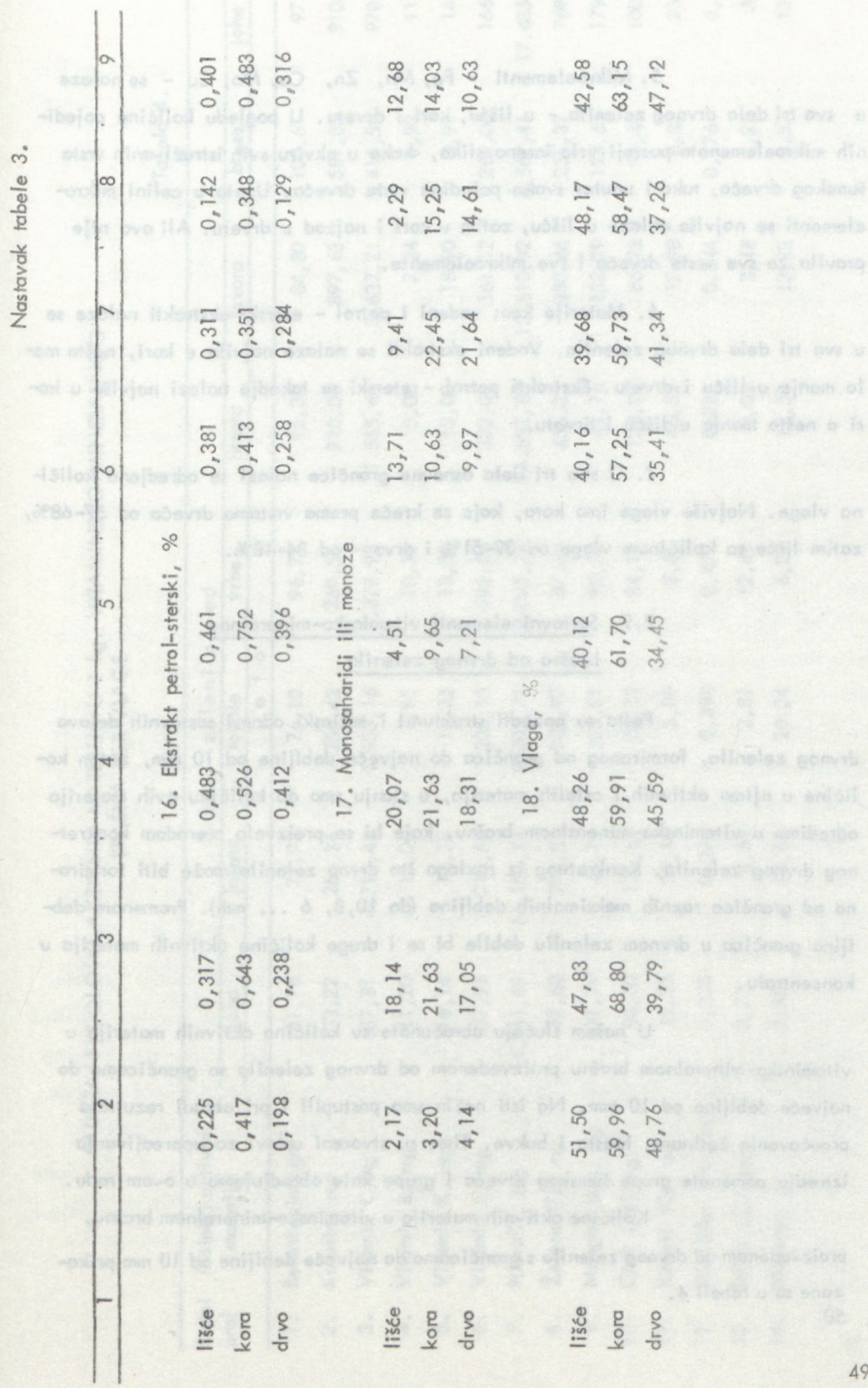


5. Mikroelementi - $\mathrm{Fe}, \mathrm{Mn}, \mathrm{Zn}, \mathrm{Co}, \mathrm{Mo}, \mathrm{Cu}$ - se nalaze u sva tri dela drvnog zelenila - u lišcu, kori i drvełu. U pogledu količine pojedir nih mikroelemenata postoji vrlo šarena slika, kako $u$ okviru svih istraživanih vrsta šumskog drveća, tako $\mathbf{i}$ unutar svake pojedine vrste drveca. Uzeto u celini mikroelementi se najviše nalaze u lišcu, zatim u kori i najzad u drvełu. Ali ovo nije pravilo za sve vrste drveća $i$ sve mikroelemente.

6. Materije kao: vodeni i petrol - eterski ekstrakti nalaze se u sva tri dela drvnog zelenila. Vodeni ekstrakti se nalaze najviše u kori, nešto malo manje u lišču i drvetu. Ekstrakłi petrol - eterski se takodje nalazi najviše u kori a nešto manje u lišču $i$ drvetu.

7. U sva tri dela osnovne grančice nalazi se odredjena količina vlage. Najviše vlage ima kora, koja se krece prema vrstama drveća od $57-68 \%$, zatim lišce sa količinom vlage od $39-51 \%$ i drvo - od $34-48 \%$.

\subsection{Sastavni elementi vitaminsko-mineralnog brašna od drvnog zelenila}

Pošto su poznati struktumi $i$ težinski odnosi sastavnih delova drvnog zelenila, formiranog od grančica do najvece debljine od $10 \mathrm{~mm}$, zatim količine u njima aktivnih $i$ ostalih materija, u stanju smo da količinu ovih materija odredimo u vitaminsko-mineralnom brašnu, koje bi se proizvelo preradom konkretnog drvnog zelenila. Konkretnog iz razloga što drvno zelenilo može biti formirano od grančica raznih maksimalnih deblijina (do $10,8,6 \ldots \mathrm{mm}$ ). Promenom deblijina grančica u drunom zelenilu dobile bi se $i$ druge količine aktivnih materija u koncentratu.

U našem slučaju obračunate su količine aktivnih materija $u$ vitaminsko-mineralnom brašnu proizvedenom od drvnog zelenila sa grančicama do najveće debljine od $10 \mathrm{~mm}$. Na isti način smo postupili i pri obradi rezultata proučavanja četinara, hrasta $i$ bukve. Time su stvoreni uslovi zc uporedjivanja izmedju pomenute grupe šumskog drveća $i$ grupe koju obradjujemo u ovom radu.

Količ ine aktivnih materija u vitaminsko-mineralnom brašnu, proizvedenom ad drvnog zelenilas grančicama do najveće debljine od $10 \mathrm{~mm}$ prikazane su $u$ tabeli 4. 


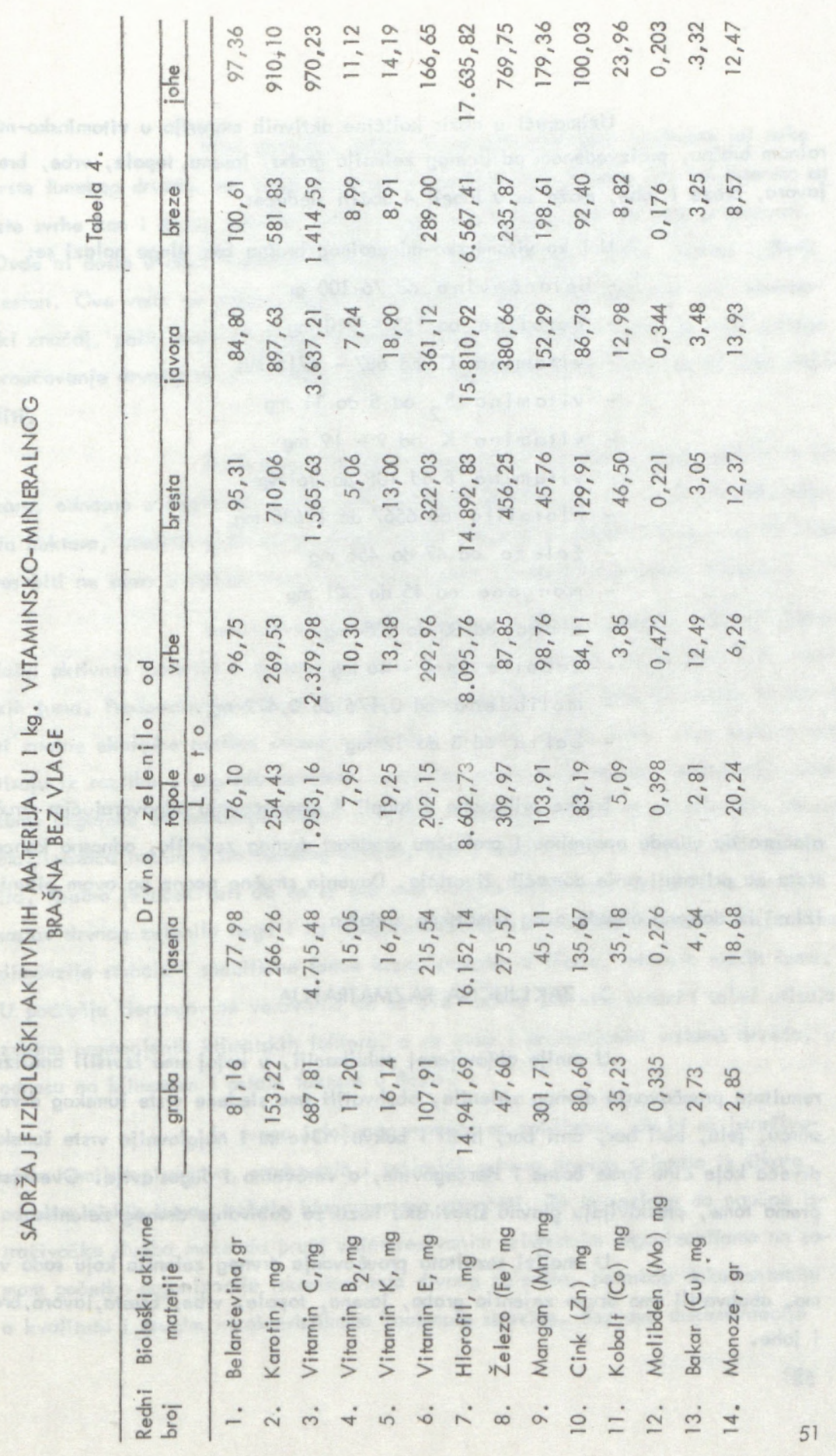


Uzimajući u obzir količine aktivnih materija u vitaminsko-mineralnom brašnu, proizvedenom od drunog zelenila graba, jasena, topole, vrbe, bresta, javora, breze $\mathrm{i}$ johe, može se u tabeli 4 uočiti sledeće:

$\bigcup 1 \mathrm{~kg}$ vitaminsko-mineralnog brašna bez vlage nalazi se:

- belančevine od 76-100 gr

- karotina od 153 - $910 \mathrm{mg}$

- vitamina $C$ od 687 - $4715 \mathrm{mg}$

- vitamina $B_{2}$ od 5 do $11 \mathrm{mg}$

- vitamina $K$ od 9 - 19 mg

- vitamina $E$ od 108 do $361 \mathrm{rgg}$

- hlorofila od 6567 do 17635 mg

- železa od 47 do $456 \mathrm{mg}$

- mangana od 45 do 301 mg

- cinka od 80 do $135 \mathrm{mg}$

- kobalta od 4- $46 \mathrm{mg}$

- molibdena od 0,176 do 0,472 mg

- bakra od 3 do $12 \mathrm{mg}$

Brojke prikazane $u$ tabeli 4 omogućavaju odgovarajućim stručnjacima da odrede upotrebnu $i$ praktičnu vrednost drvnog zelenila, odnosno koncentrata za prihranjivanje domaćih životinja. Davanje stručne ocene po ovom pitanju izlazi iz domena obrade ovog tematskog zadatka.

\section{ZAKLUUČNA RAZMATRANJA}

U ranije objavljenoi publikaciji, u kojoj smo izvršili analizu rezultata proučavanja drvnog zelenila, obuhvatili smo sledeće vrste šumskog drveća: smrču, jelu, beli bor, crni bor, hrast $i$ bukvu. Ovo su $i$ najglavnije vrste šumskog drveća koje čine šume Bosne i Hercegovine, a verovatno i Jugoslavije. Ove vrste prema tome, prestavljaju glavnu sirovinsku bazu za dobivanje drunog zelenila.

$U$ analizi rezultata proučavanja drvnog zelenila koju sada vršiino, obuhvatili smo drvno zelenilo graba, jasena, topole, vrbe, bresta, javora, breze i johe. 
Nisu. postojali uslovi da se proučavanjima obuhvate još neke vrste šumskog drveća, od kojih bi drvno zelenilo moglo takodje biti od interesa za iste svrhe kao $i$ drvno zelenilo ostalih vrsta drveća koje smo do sada proučavali. Ovde bi došle u obzir sledeće vrste drveća: lipa, bagrem, jasika, pitomi i divlji kesten. Ove vrste ne predstavljaju za područje Bosne i Hercegovine veći ekonomski značaj, pošto malo učestvuju u opštem šumskom drvnom fondu. Iz ovih razloga proučavanje drunog zelenila pomenutih vrsta šumskog drveća može se za sada odgoditi.

Medjutim, u Bosni i Hercegovini sirovinska baza postojećih šikara, odnosno u dogledno vreme budućih niskih šuma na površini od oko 800 hiljada hektara, predstavljaće za privredu zemlje realni ekonomski interes. Taj će interes biti ne samo $u$ odnosu na drunu masu, nego $i$ u odnosu na drvno zelenilo.

Verovatno da postoji osetnija razlika u pogledu sadržaja fiziološki aktivnih materija u drvnom zelenilu iz šikara, odnosno niskih šuma i iz visokih šuma. Predpostavliene nove odnose u sadržaju aktivnih materija mogle bi usloviti znatne ekološke razlike izmedju visokih $i$ budućih niskih šuma. Ove razlike rezultiraju iz razlika u pogledu boniteta zemljišta, inklinacije terena, ekspozicije (niske šume uzgojene od današnjih šikara u većini slučajeva nalaze se na prisojnim stranama), učešća raznih vrsta šumskog drveća, kao $\mathbf{i}$ raznih vrsta $u$ okviru istih radova itd. Realno je očekivati da će se sve ove razlike odražavati ne samo na hemijski sastav drvnog zelenila nego i na njegove strukturne $i$ težinske odnose s obzirom na dimenzije stabala i specifične forme krune stabala iz šikara, odnosno niskih'šuma. $U$ području Hercegovine verovatno će se ove razlike još više izrazi ‘i usled uticaja znatno promenjenih klimatskih faktora, a sa ovim $i$ promenjenim vrstama drveća, $u$ odnosu na klimatske $i$ ostale faktore u Bosni.

Iz svega izloženog nameće se zaključak, da bi sa istraživanjem hemijskog sastava, strukturnih $i$ težinskih odnosa drvnog zelenila iz šikara, odnosno niskih šuma, trebalo blagovremeno započeti. To iz razloga da naučno istraživačka služba može da pruži zainteresovanim privrednim organizacijama na samom početku organizacije iskorišćavanja drvnog zelenila, potrebnu dokumentaciju - kvalitetu i drugim karakteristikama pomenute sirovine. Bez ove dokumentacije 
ne bi se moglo pristupiti izradi investicionih programa za izgradnju postrojenja za preradu drvnog zelenila $u$ koncentrat stočne hrane.

Kada šumarsivo bude raspolagalo dokumentacijom o kvalitetu drvnog zelenila $\mathbf{i}$ iz niskih šuma, biče u stanju da ponudi zainteresovanim privrednim organizacijama raspoložive godišnje količine drvnog zelenila iz oba izvora - iz visokih šuma $i$ iz niskih šuma.

Pri oceni kvaliteta drvnog zelenila kao sirovine za proizvodnju koncentrata stočne hrane neophodno je istaći da drvno zelenilo, u odnosu na travno zelenilo, prestavlja još uvek kod nas sirovinu koja se u veoma maloj meri ili nikako tretira pesticidima u cilju zaštite od štetnih organizama. Koncentrał za prihranjivanje stoke, proizveden od ovakve sirovine, prestavljaće u savremenom svetu sve veću dragocenost, koja će vremenom sve više rasti, usled toga što primena pesticida za zaštitu bilja u svełu se sve više primenjuje. Ovo stoga što životne namirnice, proizvedene od domaćih životinja koje se prihranjuju koncentratom od nezatrovanog drvnog zelenila, kao: govedje, ovčije, svinjsko i životinsko meso, zatim jaja, mlečni proizvodi $i$ dr., neće u sebi sadržavati štetne materije, koje ugrožavaju zdravlje ljudi.

Prema orijentacionoi proceni, zasnovanoi na bazi godišnjeg etata od oko 5 miliona $\mathrm{m}^{3}$ bruto drvne mase, u Bosni i Hercegovini bi se moglo godišnje proizvesti oko 140.000 t.vitaminsko-mineralnog brašna. Ovo pod uslovom da se iskoriste sve količine drvnog zelenila koje napadaju na sečinama, što u praksi nikad neće biti moguće. U gornju procenu nije obuhvaćeno drvno zelenilo iz šikara, odnosno niskih šuma, iz razloga što nismo bili u stanju da izvršimo ni najgrublju procenu.

Sa 140.000 t.koncentrata od drvnog zelenila bilo bi moguće prihranjivati, tokom cele godine, oko 1,5 milion krava-muzara ili oko 40 miliona kokošaka - nosilica.

Pored napred izloženog bilo bi potrebno u zaključku istaći još i sledeće momente: 
1. U drvnom zelenilu svih proučavanih vrsta šumskog drveća (četinara i lišćara) najviše učestvuju lišče, odnosno četine. Na osnovnoj grančici do debljine od $10 \mathrm{~mm}$ učeș̌ce lišća iznosi od 50 - 64\% od ukupne težine osnovne grančice do $10 \mathrm{~mm}$ debljine; kod četinara učešće četina iznosi od $65-80 \%$.

\section{Posle lišća, odnosno četina, dolazi po učešću u osnovnoj} grančici do $10 \mathrm{~mm}$, debljine k o r a. Kod liščara kora učestvuje od 14-27\%, kod četinara od 11-20\% a kod hrasta i bukve - $19 \%$ od ukupne težine osnovne grančice do $10 \mathrm{~mm}$ debljine.

3. Drvo učestvuje u osnovnoi grančici do $10 \mathrm{~mm}$ debljine kod svih proučavanih vrsta lišćara, uključiv hrast $\mathrm{i}$ bukvu, od 15-31\%, i to: kod bukve $-31 \%$, graba $\mathrm{i}$ breze $-27 \%$, jasena - $23 \%$, vrbe $-22 \%$, hrasta, johe $\mathrm{i}$ javora - $21 \%$, bresta - $15 \%$ i topole - $15 \%$ od ukupne težine osnovne grančice do $10 \mathrm{~mm}$ debljine.

U osnovnoi grančici (drvnom zelenilu) četinara drvo učestvuje $\mathrm{i}$ to: kod belog bora - $15 \%$, jele - $12 \%$, crnog bora - $10 \%$ i smrče - $9 \%$ od ukupne težine osnovne grančice do $10 \mathrm{~mm}$ debljine.

4. Nosilac kvalitetne vrednosti vitaminsko-mineralnog brašna od drvnog i travnog zelenila, kao koncentrala za prihranjivanje stoke, jeste k a r o t i n. Grab, jasen, topota, vrba, brest, javor, breza i joha sadrže u letnjem periodu (za ostala godišnja doba nisu vršena proučavanja) karotina od 259-1490 $\mathrm{mg}$ u $1 \mathrm{~kg}$ suve materije lišća.

Četinari, zatim hrast $i$ bukva, sadrže takodje u letnjem periodu karotin ali u manjoj količini od napred citiranih liščarskih vrsta šumskog drveća. Zato će biti potrebno obnoviti istraživanja sadržaja karotina u četinama četinara $i$ lišću hrasta $\mathbf{i}$ bukve $u$ cilju proveravanja već izvršenih proučavanja. 
Terzić Dušan, dipl.ing.

\section{DIE ERFORSCHUNG DER CHEMISCHEN ZUSAMMENSETZUNG DES BAUMGRÜNS ALS ROHMATERIALS FÜR DIE ERZEUGUNG EINES FUTTERKONZENTRATS}

Zusammenfasung

Im ersten Teil dieser Arbeit, die unter obengenanntem Titel 1970 publiziert wurde, sind unter anderem die Forschungsergebnisse uber die chemische Zusammensetzung der physiologisch - aktiven Stoffe im Grün verschiedener Baume - des Wacholderbaumes, der Tanne, der Wei3kiefer, der Schwarzkiefer, der Eiche und der Buche - veröffentlicht worden. In dieser Publikation in deutscher Sprache wurde ein umfangreiches Resümee über die erreichten Forschungsresultate gegeben.

In diesem II. Teil der Arbeit gibt der Verfasser die Forschungsergebnisse über die chemische Zusammensetzung der physiologisch - aktiven Stoffe im Baumgrün für folgende Arten von Laubbaumen bekannt:

$$
\begin{aligned}
& \text { die Wei3buche (Carpinus betulus L) } \\
& \text { die Wei3esche (Fraxinus excelsior L) } \\
& \text { die Schwarzpappel (Populus nigra L) } \\
& \text { die Silberweide (Salix alba L) } \\
& \text { die Bergulme (Ulmus montana With) } \\
& \text { der Ahorn (Acer platanoides L) } \\
& \text { die Birke (Betula verrucosa Erh) } \\
& \text { die Schwarzerle (Alnus glutinosa Gaer) }
\end{aligned}
$$

Für diese Arten von Waldbaumen wurden Forschungen zu den Gewichts - und Strukturverhältnissen des Baumgrüns bei Zweigen bis zu $10 \mathrm{~mm}$ Starke vorgenommen.

Mit diesen Untersuchungen wurde es möglich, sowohl den Anteil des Laubes, der Rinde und des Holzes als auch den Anteil der Zweige je nach Starke der Rinde am Baumgrün festzustellen. Die Forschungsresultate über die 
Gewichts - und Strukturverhältnisse des Baumgrüns sind in den Tabellen 1 und 2 dargestellt.

In dem Teil, in dem die Erforschung der chemischen Zusammensetzung des Baumgrüns geschildert wird, hat der Verfasser die Untersuchungsergebnisse Über den Vitamingehalt (Karotin als Provitamin A, Vitamine C, B,$K$ und $\mathrm{E})$, der Spurenelemente ( $\left.\mathrm{Fe}, \mathrm{Mn}, \mathrm{Zn}, \mathrm{Co}_{0}, \mathrm{Mo}, \mathrm{Cu}\right)$ und anderer Stoffe Eiwei3e, Asche, Wasserextrakt, Monosacharide, Petrol - Atherextrakt, Chlorophyl) aufgefuhrt.

Alle Untersuchungen der chemischen Zusammensetzung wie auch andere Forschungen sind gesondert für die Blätter, für die Rinde und für das Holz der Zweige gemacht worden.

In der Tabelle 4 sind die Mengen der physiologisch - aktiven Hauptstoffe fur $1 \mathrm{Kg}$ trockenes, vitamin - und mineralgehaltiges Mehl angegeben.

Es ist notwendig, zu betonen, da3 sich im Baumgrün der erforschten Arten von Laubbäumen neben anderen bedeutungsvollen Stoffen auch merkliche Mengen des Karotins und andere Mineralien befinden.

Das bedeutet, da3 das Grün der genannten Baumarten sowohl ein wertvolles Rohmaterial für die Erzeugung eines Konzentrats für die zusatzliche Emahrung des Viehs als auch eine Grundlage für die Herstellung anderer Produkte ist. 
SPISAK FOTOGRAFIJA

SI. 1. Eksperimentalna stanica u Maoči: merenje težinskih i strukturnih odnosa u drvnom zelenilu (Foto Terzić, 1970.)

SI. 2. Beli jasen (Fraxinus excelsior L.)

SI. 3. Cma topola (Populus nigra L.)

SI. 3a. Bela vrba (Salix alba L.)

SI. 4. Gorski brest (Ulmus montana With.)

SI. 5. Cma joha (Álnus glutinosa Gaer.) 
PREDGOVOR AUTORA

1. CILJ ISTRAZIVANJA 4

2. REZULTATI PROUČAVANJA SA ANALIZOM I ZAKLUČCIMA 7

2.1. Objekti proučavanja 7

2.2. Proučavanje težinskih odnosa ú drvnom zelenilu 8

2.3. Proučavanje strukturnih odnosa u drvnom zelenilu $\quad 17$

2.4. Proučavanje hemijskog sastava drvnog zelenila 31

2.5. Vitamini 31

2.51. Karotin - provitamin A 31

2.52. Vitamin C 32

2.53. Vitamin $\mathrm{B}_{2} \quad 33$

2.54. Vitamin $\mathrm{K}^{2} \quad 33$

2.55. Vitamin E 34

2.6. Mikroelementi 35

2.61. Željezo $(\mathrm{Fe}) \quad 35$

2.62. Mangan $(\mathrm{Mn}) \quad 36$

2.63. Cink $(\mathrm{Zn}) \quad 37$

2.64. Kobalt (Co) 37

2.65. Molibden (Mo) 38

2.66. Bakar $(\mathrm{Cu}) \quad 39$

2.7. Ostale materije u drvnom zelenilu $\quad 40$

2.71. Belančevine $\quad 40$

2.72. Pepeo 41

2.73. Ekstrakt vodeni 41

2.74. Monosoharidi ili monoze 42

2.75. Ekstrakt petrol-eterski 43

2.76. Hlorofil 43

2.8. Uporedna tabela rezultata proučavanja drvnog zelenila 44

2.9. Sastavni elementi vitaminsko-mineralnog brašna od
drvnog zelenila

3. ZAKLUUČNA RAZMATRANJA 52

Zusammenfasung $\quad 56$ 
andiand

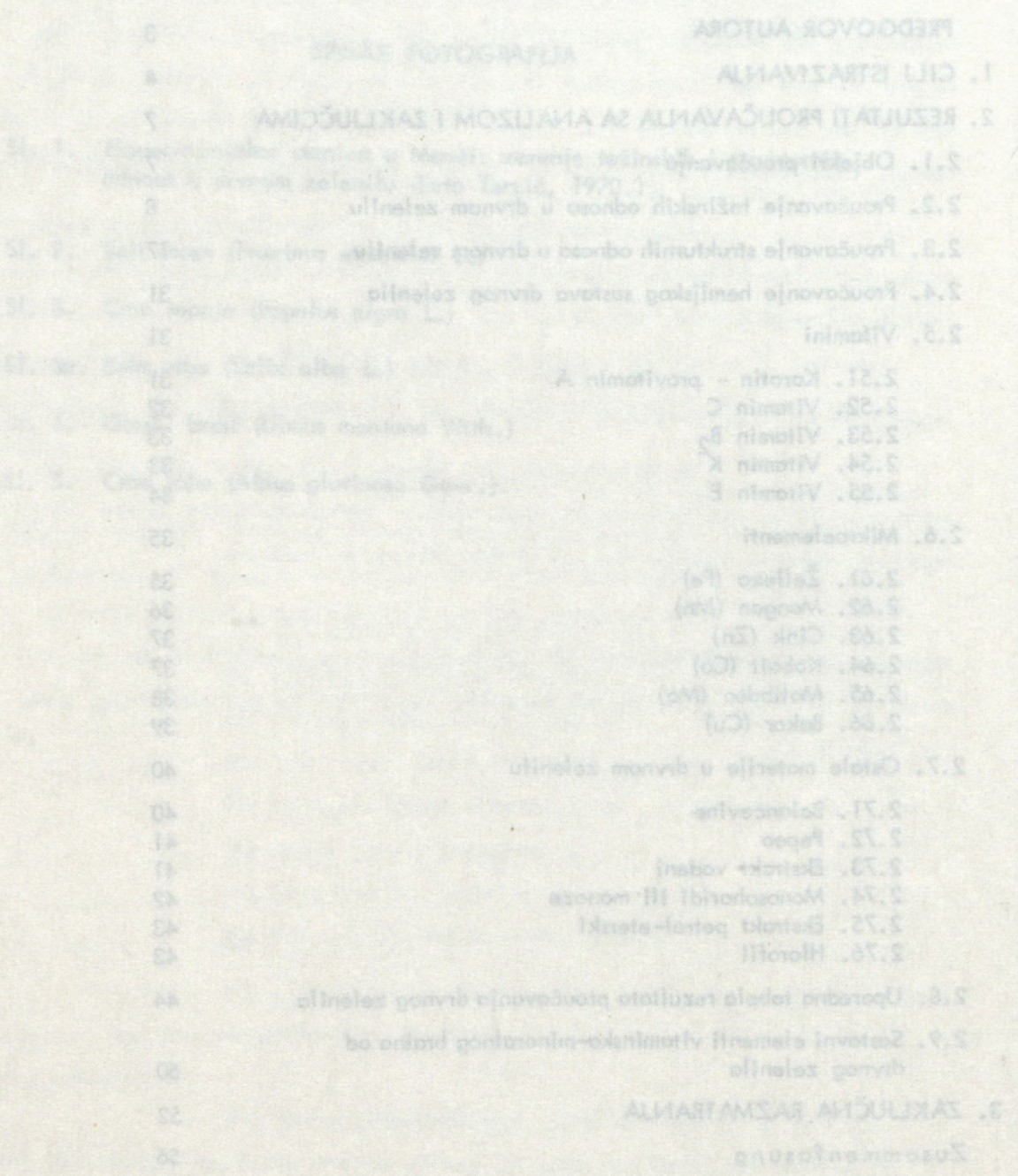


